\title{
Musul Kazası'nın Cizyegüzârları ve Bölgesel İlişkileri (XVII. Yüzyılın Son Çeyreği)
}

\author{
Ŏguzhan Samıkıran*
}

Poll Tax (Jizya) Payers of the Mosul Kaza and Its Regional Relationships (The Last Quarter of $17^{\text {th }}$ Century)

Abstract $\square$ To determine the contribution of the poll tax registers (jizya defters) on the history of Ottoman non-Muslims and the Ottoman city has been considered as a problem within the scope of the relationship between the Ottoman city and the non-Muslims.

The main purpose of the research is to reveal the both urban and rural settlements of non-Muslims in Mosul Kaza; the characteristics of migrations and immigrants; the spatial organization of crafts; the regional relations of Mosul and the effects of variola.

The objectives of the research are: What are the urban-rural population and the income level? What is the impact of the conceptual confusion in the register terminology to determine both social and demographic features? What is the relationship between the quantities and qualities of crafts and the features of mahallas (quarters)? What is the reason of disproportion in the number of master-apprentice? What is the relationship between the contents of poll tax registers that belong to the cities which have border for neighboring countries and the Ottoman border policies? What is the relationship between the spread of variola and weaving?

This research is based on the poll tax register of the Mosul Kaza dated 1103/1691-92. Various documents and registers in the Ottoman Archives (in İstanbul) and sharia court records of Diyarbakır and Mardin have been used in order to interpret the data in the register.

The following findings have been obtained: $49 \%$ of the native non-Muslims in the kaza have been habitant in the city and $64 \%$ of them was ednâ (low-class in terms

* Hatay Mustafa Kemal Üniversitesi. 
of income level). The rate of ednâs in rural areas was $77 \%$. In the city, the migrants from rural areas (the rate is 29\%) and different cities (the rate is 61\%) have been encountered. Rencbers who constituded the majority of scattered (perakende) poll taxpayers that are classified as "who do business/work in the city" and "who are pass-byers" included porters, crafts and capital owners. The majority of rencbers, architects, jewelers, saddlers, weavers, and the craftsmen who composed of the subsectors of weaving was in the mahalla of Dergâh-1 Nestûrî. The crafts who played role in the production of the river transportation vehicles had concentrated in the same mahalla. Some Muslim apprentices worked with non-Muslim masters. The rate of apprentices in the city was $13 \%$. The rate of immigrant apprentices was $26 \%$. $1 / 3$ of the jewelers and $31 \%$ of the sword maker was composed of immigrants. There were no non-Muslim bakers, butchers, millers and horseshoers in Mosul. The variola mainly affected the tailors, rencbers, weavers, painters, and carpenters. The traces of the Ottoman poll tax have been founded in the proverbs.

The rural poverty has been higher than the urban poverty even if there was no significant difference between rural and urban population in terms of non-Muslims. The low income level in the rural areas in addition with the employment areas and the trade that the administrative and geographical location of Mosul provided directed labor, craft and capital (low or high) owners to the city and particularly the busy mahallas of the city.

Keywords: Poll Tax (Jizya) Registers, Non-Muslims in the Ottoman Empire, Jews and Christians of Mosul, Crafts and Craftsmen of the Middle East, Migrations and Immigrants in the Middle East, Smallpox in the Ottoman Empire, Turkish and Arabic Proverbs

\section{Giriş}

Osmanlı, cizye tahsilinde "mükellefiyet yaşı"nın tespitinde sorunlar yaşıyordu. ${ }^{1}$ Bu sorunları aşmada geliştirdikleri yöntem ve uygulamalara dair bilinenler sınırlıdır. Tournefort, cizye tahsiliyle kafa ve boyun gelişimi arasındaki ilişkiyi vurgulamıştır: "Cizye ödemesi gerekenleri saptamak için, bir iple boyun ölçüsü alınır; daha sonra ipin iki ucu, ölçüsü alınan şahsın dişleri arasına konup ölçü tam iki katına çıkarılır; eğer baş ipe hiç değmeden bu ölçünün içinden geçiyorsa o şahsın cizye ödemesi gerekir, eğer başı geçmiyorsa cizye vermez."2

1 Boris Christoff Nedkoff, “Osmanlı İmparatorluğunda Cizye (Baş Vergisi)”, Şinasi Altundă̆ (çev.), Belleten, VIII/32 (1944), s. 623.

2 Joseph de Tournefort, Tournefort Seyahatnamesi, Ali Berktay (çev.), Stefanos Yerasimos (ed.), (İstanbul: Kitap Yayınevi, 2013), I, s. 249. 
Fiziksel gelişim ve iktisadi vaziyet ile cizye mükellefiyeti arasında bağı açıklayan veriler mevcuttur. Mesela emred ve mürâhık (bıyığı terlemiş oğlan) olduğu ve büluğa ulaştığı kanıtlandığında, kişi cizyegüzâr/cizye mükellefi (cizye ödeyen kimse) olabiliyordu. ${ }^{3}$ Büluğa ermeyenlerden cizye alınmazdı. ${ }^{4}$ Kazanç sağlamasını önleyen kötürümlük, noksanlık, felçlik veya hastalıklı olmak gibi sahih özrü olmayanlardan tahsil edilirdi. ${ }^{5}$ Ayrıca geçimini sağlayacak uğraşa iktidarı olmayıp sadakalarla geçinenler, ${ }^{6}$ pîrî fâni (oldukça yaşlı) olduğu ve kisb u kâra (iş ve kazanca) kadir olmayıp fakirliği onaylananlar ödemezdi. ${ }^{7}$ Nafakanın kazanılmasına engel olan elin/kolun yaralı olması da yükümlülüğü önlüyordu. ${ }^{8}$ Bedenen olgun ve sıhhatli olması, iaşesi için bir uğraşa sahip olması, ticaretle geçimini sağlaması, yani bir amele kadir olması kişiye külfet getiriyordu. Yani kisb u kâr karşıllğında cizye ödüyordu. ${ }^{10}$ Kısacası mükellefiyet, öncelikle kimseye gereksinmeden ekmeğini kazanabilecek güce ve olgunluğa ermeyi ve bunun da ispatını gerektiriyordu.

Bedensel gelişimle birlikte toplumsal ve iktisadi yapıyla doğrudan ilişkili olan "boyun (rekabe) ve kafanın (re’s) iple ölçümü” uygulamasının, "Kurda 'boynun niçin kalındır?' demişler, 'işimi kendim görürüm de ondan' demiş"11

3 İstanbul örneği için bkz. Başbakanlık Osmanlı Arşivi (BOA), Kamil Kepeci (KK.d) nr. 3509, (8 Muharrem 1107/19 Ağustos 1695), s. 133.

4 Sofya örneği için bkz. BOA, KK.d nr. 3509, 26 Temmuz 1695 (14 Zi'l-hicce 1106) , s. 131.

5 Başbakanlık Osmanlı Arşivi (BOA), İbnü’l-Emîn-Dâhiliye (İE.DH) 9/913, 15 Kasım 1691 (23 Safer 1103).

6 Başbakanlık Osmanlı Arşivi (BOA), 'Alî Emîrî-Ahmed II (A.E.SAMD II) 18/1977, 22 Haziran 1694 (28 Şevvâl 1105). “...sağ kolum mecrûh ve 'amel-mânde ve kâr ve kisbe kâdir olmayub asla menzilim ve emlâkım ve bir habbem olmayub harabdır geçünürüm bir etmeğe (ekmeğe) muhtâc ...”. Edirne örneği için bkz. BOA, KK.d nr. 3509, 10 Mayıs 1695 (26 Ramazân 1106); “...kâr u kisb eylemediğimiz ecilden yave cizyesi taleb olunmaz ...”. Edirne örneği için bkz. Başbakanlık Osmanlı Arşivi (BOA), Maliyeden Müdevver Defterler (MAD.d) nr. 9848, 14 Temmuz 1667 (22 Muharrem 1078), s. 148.

7 Balıkkesir örneği için bkz. BOA, KK.d, nr. 3508, 16 Nisan 1692 (29 Receb 1103), s. 97.

8 BOA, KK.d, nr. 3509, 31 Temmuz 1694 (8 Zi'l-hicce 1105), s. 26.

9 İstanbul örneği için bkz. BOA, KK.d nr. 3508, s. 48 (sonraki belgenin tarihi: 4 Şa ‘bân 1103/21 Nisan 1692).

10 Halep örneği için bkz. BOA, MAD.d, 9848, 6 Cemâziye’l-evvel 1077 (4 Kasım 1666), s. 36, Vize ve Kırkkilise için bkz. BOA, MAD.d, nr. 9848, s. 129; BOA, KK.d, nr. 3508, 9 Temmuz 1691 (12 Şevvâl 1102), s. 30.

11 Samed Alizâde, Oğuznâme (Emsâl-i Mehmedali) XVI. yy.da Yazılmıs Türk Atasözleri Kitabı, Ali Haydar Bayat (haz./yay.), (İstanbul: Türk Dünyası Araştırmaları Vakfı, 1992), s. 67; Güvâhî, Pend-nâme (Ö̈̆ütler ve Atasözleri), Mehmet Hangirmen (haz.), (Ankara: Kültür 
atasözüyle ilişkisi; birçok örf, adet ve inançların zamanla coğrafî şartların, farklı kültürlerle ilişkilerin, dinin ve hâkim devletlerle beyliklerin yaptırımlarının etkisiyle toplumun söz dağarcığına giren cizye uygulamasının kalıntılarına mı işarettir? Nitekim bir olayı veya bir işi temsil yoluyla tanımlamakla birlikte bir hükmü içeren atasözleri, ${ }^{12}$ toplumsal ve kültürel kodlu belirli bir vakıanın ve tecrübenin değerler süzgecinden geçirilerek fikren onaylanması neticesinde türemektedir. ${ }^{13}$ Ayrıca atasözünü söyleyen kişi "o sözün varacağ yaklaştırarak ve benzeterek söyler". ${ }^{14}$ Bir milletin toplumsal ve kültürel açıdan geçirdiği evreleri yansıtan ${ }^{15}$ atasözlerini Aksoy, "atalarımızın uzun denemelere dayanan yargılarını genel kural, bilgece düşünce ya da öğüt olarak düsturlaştıran ve kalıplaşmış biçimleri bulunan kamuca benimsenmiş özsözler” olarak tanımlamıştır. ${ }^{16}$ Kısacası atasözlerinin ortaya çıkmasında toplumsal bir gerçek ve yaşantı esas teşkil etmekteydi.

Osmanlı́nın tatbik ettiği vergi uygulamalarının halkın edebî kültürü üzerinde etkili olduğunu gösteren ve emsal teşkil eden en seçkin örnek Musul toplumunun söz dağarcığına yerleşen ve halk ağzıyla (âmmice) kaydedilen bir Musul atasözünde görülmüştür: "Misl Yehûdî mahbûs 'alâ temittu' (Yahudi temettüyü ${ }^{17}$ ödemekle yükümlüdür)”. ${ }^{18}$

Halep toplumunda da benzeri atasöze rastlanmıştır: "Vechu mitl defteri'ttemettu' (yüzü temettü defteri gibi)". Yani insanın hoşlanmadığı bir yüz (vech), tebaa tarafından yine hoş karşılanmayan ve münker kabul edilen vergi defterine (temettu'ât defteri) benzetilmiştir. Çoğunlukla evrilip çevrilmesi neticesinde

ve Turizm Bakanlığı Yayınları, 1983), s. 65; Şinasi İbrahim, Durûb-u emsâl-i 'Osmâniyye, (Kostantıniyye: Matba'a-1 Ebu’z-Zıyâ, 1302), s. 370.

12 Şinasi İbrahim, Durûb-u emsâl, s. 509.

13 İhsan Kurt, Türk Atasözlerine Psikolojik Bir Yaklaşım, (Ankara: Kültür Bakanlığı Yayınları, 1991), s. 1-2.

14 Ahmet Vefik Paşa, Atalar Sözü Müntehabât-ı Durûb-ı Emsâl, Recep Duymaz (haz.), (İstanbul: Gökkubbe, 2005), s. 20.

15 Dehri Dilçin, Edebiyatımızda Atasözleri (1. Kitap), (İstanbul: Türk Dil Kurumu Yayınları, 1945), s. XIV.

16 Ömer Asım Aksoy, Atasözleri ve Deyimleri Sözlüğ̈̈ I Atasözleri Sözlüğ̈̈, (Ankara: Ankara Üniversitesi Basımevi, 1971), s. 36.

17 Temettü', XIX. yüzyılda alınan bir çeşit vergidir.

مثل ايهودي محبوس على تمتع 18 . bkz. Muhammed Ra’ûf el-Gulâmî, Kitâbül-müreddedi'lemsâli'l-âmmiyyeti'l-Mevsıliyyeti, Mü' eyyed el-Gulâmî (nşr.), (Bağdâd: Matba'atü’ş-Şefîk, 1384/1964), s. 142. 
defterde oluşan buruşuklukla, istemeyerek vergi verenin buruşmuş/bükülmüş/ ekşi yüzü kastedilmiştir. ${ }^{19}$

Yukarıda geçen atasözündeki "boyun" ibaresi de rastlantı sonucu kullanılmamıştır; çünkü Subhî Tarihi'nde geçen "âmme-i Nasârâ ve Yehûd ve Kıbt'ın cizye-i rekabeleri ${ }^{20 "}$ ibaresi ${ }^{21}$ cizye-boyun ilişkini vurgulamaktaydı. Sözlüklerde boyun kelimesi "uhde" ve "zimmet"; boyuna almak, "taahhüd" ve "zımân"; boyun borcu, "farîza" ve "vâcib 'ale'z-zimme"; boynu ince, boyun vermek ve boyun kesmek ise "itaat" anlamındadır. ${ }^{22}$ Boyun olmak ise "kefil, mütekeffil ve zâmin olmak; tazmin ve tekeffül etmek" anlamlarındadır. ${ }^{23}$ Nitekim "İslâm Devleti'nin kefaleti altında bulunan" zimmi, "baş üzerine vazedilen" ve devletle ehl-i zimmet arasında "karşılıklı bir muahede" olan cizyeyi ödemekle mükellefti. Aykırı davranmak devletin taahhüt ettiği himayenin kalkmasına, hapis cezasına ve hatta zimminin hayatına mal olabilirdi. ${ }^{24}$

Musul Kazası ${ }^{25}$ 'yla bağı bulunan yerli ve yabancı (ecnebi) cizyegüzârların ${ }^{26}$ sayılarını, yerleşimini ve uğraşlarını ve meslekler açısından kazanın bölgesel

19 bkz. El-Eb Yûsuf Kûşâkc1, el-Emsâlü̧ş-şa ‘biyyetü’l-Halebiyye ve emsâlü Mârdîn, (Haleb: Matba'atü'l-İhsân, 1978), el-cüz'ü’s-sânî, s. 580.

20 Arapçada rekabe (رَقَبَّة), "boyun” anlamındadır.

21 Vak'anüvis Subhî Mehmed Efendi, Subhî Tarihi, Sâmî ve Şâkir Tarihleri ile Birlikte 17301744 (Inceleme ve Karşılaştırmalı Metin), Mesut Aydıner (haz.), (İstanbul: Kitabevi Yayınları, 2007), s. 234.

22 Mehmed Ali el-Ünsî, Kâmûsül-lügati'l-'Osmâniyyeti'l-müsemmâ dırârül-lâmi âti fî müntehabâti’l-lügâti, (Beyrût: Matba'a-1 Cerîde-i Beyrût, 1318), s. 130-131.

23 Mertol Tulum, 17. Yüzynl Türkçesi ve Söz Varlı̆ğ, (Ankara: Atatürk Kültür, Dil ve Tarih Yüksek Kurumu Türk Dil Kurumu Yayınları, 2011), s. 452.

24 Nedkoff, “Cizye (Baş Vergisi)”, s. 605, 606, 607.

25 Musul Sancağı Bağdat, Şehr-i Zor, Lahsa ve Basra yolu üzerinde bulunuyordu. Başbakanlık Osmanlı Arşivi (BOA), Mühimme Defterleri (A.DVNS.MHM.d) 40, 135/296. Musul ayrıca Osmanlı'nın doğuda Safevilere karşı sağlam bir seddini (sedd-i sedîdi) oluşturuyordu. BOA, A.DVNS.MHM.d 87, 87/246. İncelenen dönemde Musul Kazası, Musul Eyaleti'nin merkeziydi. Musul Kazası, Diyarbakır'dan Haleb'e giden anayol üzerindeydi. Evliya Çelebi, Seyâhatnâme (III. ve IV), Seyit Ali Kahraman (haz.), (Ankara: Atatürk Kültür, Dil ve Tarih Yüksek Kurumu Türk Tarih Kurumu Yayınları, 2013), I, s. 59a. Musul, Dicle'nin her iki tarafına yayılan bir vilayet olup merkezinin adıyla bilinmekteydi. Kuzeyde Van ve Diyarbakır vilayetleri, batıda (Şehr-i) Zor Mutasarrıflığı, güneyde Bağdat Vilayeti ve doğudaysa İran'la çevriliydi. Şemseddin Sami, Kâmûsül-Â'lâm, (İstanbul: Mehrân Matba'ası, 1316), VI, s. 281.

$26 \mathrm{Bu}$ çalışmada “yerli” kavramı Musul Kazası'nda bulunma sebebi geçici olmayıp kalıcı olan Musul ahalisini, Musulluyu yani Musul'un yerlisini tanımlamak için kullanılmıştır. 
ilişkilerini kapsayan müstakil bir çalışma şu ana kadar gerçekleştirilmemiştir. Ancak Musul'un fiziki, idari, demografik, toplumsal ve iktisadi yapısına ilişkin çalışmalar yapılmıştır; ${ }^{27}$ ed-Dîveci, çalışmalarında arşiv kaynaklarına başvurmadan genellikle Musul'un ticareti, zanaatı, çarşıları, esnafının nizamı, kiliseleri ve manastırları hakkında bilgiler vermiştir, fakat cizyegüzârlar ve mesleklerine dair herhangi bir bilgiye değinmemiştir. ${ }^{28}$ Bayatlı tahrir defterlerini kullanmıştır. Fakat sadece cizyegüzârların yaşadıkları köylerle, ${ }^{29}$ Müslim, Hristiyan ve Yahudi olarak sınıflandırmadan, mahallelerini hane sayılarıyla vermiştir. ${ }^{30}$ Gündüz ün çalışmasında ise Hristiyan ve Yahudilerin yaşadıkları mahalleler, köyler ve nüfusları hakkında sayısal veriler sunulmuştur ${ }^{31}$ ve -Bayatlidan farklı olarak- miktarlarryla birlikte 35 esnafın ismi verilmesine rağmen, ${ }^{32}$ bunların dinî kimliğiyle sakin oldukları mahalleler belirtilmemiştir. Khoury 3813 numaralı defterden yararlanmıştır, ancak verdiği bilgiler sayısal değerlerle sınırlıdır. ${ }^{33}$ Rafầîl Bâbû İshak'ın çalışmasında da Osmanlı'ya ayrılan bölümde Musul'daki Hristiyan ve Yahudilerin mahalleri ve meslekleri işlenmemiştir. ${ }^{34}$ Hristiyan ve Yahudilerin yaşadığı mahalle ve meslekleri içermemekle beraber hem konu hem yoğunlaştığı dönem

"Yabancı" kavramı ise ticaret, zanaat, işçilik, seyahat ve ziyaret gibi sebeplerden farklı bölgelerden Musul Kazası'na gelen Osmanlı reayası için kullanılmıştır. Çelebi yabancıları "gurebâ" olarak tanımlamıştır. Evliya Çelebi, Seyâhatnâme (III. ve IV), s. 402 b.

27 Nilüfer Bayatlı, XVI. Yüzyılda Musul Eyâleti, (Ankara: Türk Tarih Kurumu Basımevi, 1999); Dina Rizk Khoury, Osmanlı Imparatorluğu'nda Devlet ve Taşra Toplumu Musul, 1540-1834, Ülkün Tansel (çev.), (İstanbul: Tarih Vakfi Yurt Yayınları, 2003); Ahmet Gündüz, Osmanlı İdaresinde Musul (1523-1639), (Elazığ: Fırat Üniversitesi Basımevi, 2003).

28 Sa î̀d ed-Dîveci, "Kal'atü’l-Mevsıl fî muhtelifi'l-'usûri”, Mecelletü Sûmer, el-mücelledü'l-âşir, el-cüz'ü'l-evvelü (1954), s. 1-24; aynı yazar, "Cisrü'l-Mevsıl fî muhtelifi'l-'usûri”, Mecelletü

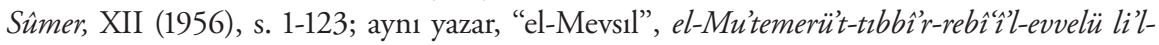
cem 'iyyeti't-tıbbiyyeti'l-Irâkıyyeti bi'l-iştirâki ma fer 'üll-cem 'iyyeti bil'-Mevsıl, (1964), s. 1-16; aynı yazar, Târîhül-Mevsıl, II, (Basım yeri yok: Basımevi yok, 2001); aynı yazar, "Sınấtü'n-nesîci fìlMevsıl”, bi-münâsebeti ihtifâlâti'l-münşe’atül-âmmeti li'l-gazeli ve’n-nesîci fîl-Mevsil bi-mürûri "30" 'âmmen 'alâ bedelihâ bi'l-intâci 26/03/1957-26/03/1987, (1987); aynı yazar, TicâretülMevsil fî muhtelifi'l-usûri, (el-Mevsıl: Müdîriyyetü Dâri İbni'l-Esîr li't-tıbâa ve’n-neşri, 2013).

29 Bayatlı, Musul Eyâleti, s. 46, 48, 49, 50, 51, 52, 57, 60, 62, 68, 76, 77.

30 Bayatlı, Musul Eyâleti, s. 111-117.

31 Gündüz, Osmanlı İdaresinde Musul, s. 94-95, 144, 146, 147,154, 159, 160, 162, 163, 165, 167 , 168, 170, 175, 184, 187, 188, 237-250.

32 Gündüz, Osmanlı İdaresinde Musul, s. 103-104.

33 Khoury, Devlet ve Taşra Toplumu, s. 47, 60.

34 Rafầîl Bâbû İshak, Târîhü Nasârâül-'Irâk münzü intişârü̉n-Nasrâniyye fill-âktâri'l-'Irâkiyye ilâ eyyâminâ,, (Bağdad: Matba'atü'l-Mansûr, 1948), s. 122-155. 
hem de Musul'un idari statüsü itibariyle araştırmamızın dışında kalan çalışmalar da mevcuttur. ${ }^{35}$

XVII. yüzyılın sonlarında özellikle kaza merkezlerinin tahririndeki içerik yoğunluğu, yerleşim ve mesleklere dair tespitleri arttırmıştır. Cizye kâğıttları ${ }^{36}$ ise defterlerdeki kayıtların tespitinde figüran rolünü üstlenmiştir. Söz konusu çalışmalardan farklı ve daha özellikli olan bu araştırmanın amacı, Musul Kazası'ndaki yerli ve yabancıların şehirde ve kırsaldaki dağılımlarına, mesleklerine ve bölgesel kimliklerine göre yerleşimlerini, iktisadi yapılarını ve kazanın bölgesel ilişkilerini açıklamaktır. Burada serhat şehri olma vasfının, kazayı ve esnafı nasıl etkilediği, ticaret yolu üzerinde ve nehir kenarında bulunan Musul Kazası'ndaki Hristiyan ve Yahudi esnaf ile bu esnafın yerleşim bölgeleri ve aralarındaki bağların keyfiyeti, yabanciların geldikleri şehirlerin neden -kuzeyden güneye bir hat şeklinde düşünüldüğünde- Tokat-Kilis-Halep hattının doğusunda ve güneyde ise -Bağdat hariç- Halep ile sınırlı kaldığı meseleleri üzerinde durulmuştur.

Makalede varılan sonuçların esas dayanağı, Başbakanlık Osmanlı Arşivi'ndeki Kamil Kepeci Cizye Muhasebe Kalemi Tasnifi'nin 3813 numaralı ve 1103/1691-92 tarihli Musul Kazasi'na ait cizye defteridir. ${ }^{37}$ Bu defter, sadece cizyegüzârların kayıtlı olduğu Musul Kazası'nın merkezindeki mahallelerle kazaya tabi köyleri kapsamaktadır.

\section{Musul Kazası'nın Merkezindeki Cizyegüzârlar}

Seyyahlar, şehri kısmen de olsa tasvir etmiştir. Mesela 1644'ün baharında Musul'a uğrayan Tavernier şehirde iki köhne kervansarayın olduğunu, şehir içinin neredeyse harabeye döndüğünü ve bakımsız çarşılardan ve paşanın küçük konağından başka görülmeye değer bir şeyin olmadığını kaydetmiştir. ${ }^{38} 1655^{\prime}$ in

35 Sinan Marufoğlu, Osmanlı Döneminde Kuzey Irak (1831-1914), (İstanbul: Eren Yayıncılık, 1998), s. 78-84, 210-212; Davut Hut, "Musul Vilayeti’nin İdarî, İktisadî ve Sosyal Yapısı (1864-1909)”, (Doktora Tezi, Marmara Üniversitesi, 2006) s. 341-353.

36 Cizye tahsilinden sonra cizyegüzârlara verilen cizye kâğıtlarına varaka, evrak, tezkere veya temessük de denmekteydi.

37 "Defter budur ki bin yüz üç senesinde Musul Kazasi'nda vâki" nefs-i Musul ve kurâları ve perakende olan cizye alınan kefere tẩifesinin esâmeleridir ki kayd olunmuşdur sene 1103 (16911692)”. BOA, KK.d, nr. 3813, s. 1.

38 Jean Baptiste Tavernier, Tavernier Seyahatnamesi, Teoman Tunçdoğan (çev.), Stefanos Yerasimos (ed.), (İstanbul: Kitap Yayınevi, 2010), s. 205. 
güzünde şehre gelen Evliya Çelebi ise Musul'u "bu çölistânda bir şehr-i ma'mûr" olarak betimlemiştir. ${ }^{39}$ Seyyahların tasvirindeki zıtlığa dikkat çekilerek, "şehir ve medeniyet algıları" ile şehre dair farklı tasvirleri arasında bağ kurulması $1^{40}$ makul karşılanabilir; ancak Tavernier, 1623'ten 1639'a kadar süren Osmanl-İran savaşlarının üçüncü safhasının Kasr-1 Şirin Anlaşması'yla bitmesinden ${ }^{41}$ beş yıl sonra, yani 1053/1643-44'te büyük bir taunun olduğu y1l, ${ }^{42}$ Musul'a gelirken -ki Musul, hududundaki savaşın izlerini hala silememiş olması muhtemeldir- Çelebi takriben on yedi yıl sonra gelmiştir. Bu yüzden Çelebi'nin ziyaretine kadar geçen zamanda Musul'un yeniden imarı da mümkündür.

Hristiyan ve Yahudileri mesleki ve yerleşim dağılımlarına dair, birinci elden kaynaklara nazaran, bilgi sunmasa da Musul'dan sıklıkla geçen Avrupalı seyyahlar Hristiyanlardan bahsetmiştir. ${ }^{43}$ Mesela Tavernier, Rumlar, Ermeniler, Nesturiler ve Marunilerden bahsetmiştir. 1798'e kadar Nesturiler, Fırat ve Dicle arasındaki kasabaları bırakarak kuzeydeki dağlara yerleşti. Yakubilerin çoğu ise Musul'da ve buraya bağlı köylerde kaldı. ${ }^{44}$ Tavernier ayrıca bir kilisesi olan Kapusenlere de değiniyordu. ${ }^{45}$ Bunlardan bir grup 1636 'da Musul'a gelerek hekimlik yapmış ve Musullular da onlara yardımda bulunmuştu, fakat 1724'te Musul'dan ayrıldılar. ${ }^{46} \mathrm{Bu}$ süre zarfında hekimlik yapmalarına rağmen, cizye defterinde sadece (perakendelerden) bir hekimin kaydedilmesi ilginçtir (bkz. Tablo-3). Muhtemelen hekimlikleri, kâr güdülen bir meslek icrası dışındaydı ve çift ve emlak ile alakaları olmayıp tıbbi tecrübeleri, insanların sadakalarına mazhar olmalarını sağliyordu.

Musul'daki Katolikler ise 1747 'de on aile Keldani ve on aile Süryanilerden oluşuyordu. ${ }^{47} 1754$ 'te Musul'u ziyaret eden Edvard İves şehirde Katolik, Nesturi

39 Evliya Çelebi, Seyâhatnâme (III. ve IV), s. 399b.

40 Davut Hut, "Evliya Çelebi ve Musul”, Evliya Çelebi Atlası, Coşkun Yılmaz (ed.), (İstanbul: Medam Yayınları, 2012), s. 259.

41 İsmail Hakkı Uzunçarşılı, Osmanlı Tarihi, (Ankara: Türk Tarih Kurumu Basımevi, 1995), III/1, s. 205, 206.

42 Yâsîn bin Hayrullah el-Hatîb el-Ömerî, Meniyyetüll-udebâ'i fî târîhi'l-Mevsıli'l-hadbâ', Sa îd ed-Dîveci (nşr.), (el-Mevsıl: Matba'atü'l-Hedef, 1374/1955), s. 175.

43 E. Honigmann ve C. E. Bosworth, "Al-Mawsıl”, Encyclopaedia of Islam 2nd, 1991, VI, s. 901. 44 Rafầil, Târîhü Nasârâül-'Irâk, s. 137.

45 Tavernier, Tavernier Seyahatnamesi, s. 205.

46 Rafầil, Târîhü Nasârâül-'Irâk, s. 123.

47 Rafầil, Târîhü Nasârâül-'Irâk, s. 130. 
ve Yakubilerin bulunduğunu kaydetmiştir. ${ }^{48}$ Oysaki Çelebi, dönemine dair Musul'daki Hristiyan ve Yahudilere değinmemiştir. Bunda seyyahların tabi oldukları dinî duyguların yaratmıs olduğu algının etkili olması muhtemeldir. Bu toplulukların yerleşim, nüfus ve mesleklerine dair veri kıtlı̆̆ı, cizye tahsiliyle ilgili düzenlemelerin yapıldığı dönemde, XVII. yüzyılın son çeyreğinde, tahrir edilen cizye defterleriyle kısmen giderilmişti. Önceleri vakıflara hâsıl olan cizye ile hazineye ait olan cizyenin tarh ve tahsilinde bir nizam yoktu. Bu yüzden 1101/1689-90 yılında Köprülüzade Fazıl Mustafa Paşa döneminde cizyenin, üç sınıf üzerinden ve tek elden toplanarak Cizye Kalemi'ne gelir kaydedilmesine ve vakıfların da kendilerine ait cizye hasılatını hazineden almaları kararlaştırılmışıı. Ayrıca âlâ, evsat ve edna ${ }^{49}$ adlarıyla farklı mühürler kazdırılması ve mühür tarihlerinin her yıl değiştirilmesi kabul edilmişti. Devletin cizyeyi tahsiline, cizyegüzârın ise tediyesine delil olarak her yıl farklı renklerde (sarı, beyaz, kırmızı) kâğgtlar hazırlanarak mühürlenmiş ve tahsil esnasında cizyegüzârlara verilmişti. ${ }^{50} 1691$ 'den önce de kâğıtlar dağıtılıyordu. ${ }^{51}$ Hatta tahsilde maktu veya haneye bağlilık kabul edilmiyordu. $\mathrm{Bu}$, mühürlü ve nişanlı defter gereğince, cizyenin tahsil edilmediğini gösteriyor. 1691'de her bir statünün miktarı önceden ayrı ayrı -fazladan- belirlenerek tezkere şeklinde tahsildarlara verilmeye başlanmıştı. 1691 öncesinde renkli cizye kâğıdı uygulamasına dair bir emre rastlanmadı. Bu, tezkerelerdeki renk uygulamasının 1691'de başladığını gösteriyor. Çünkü J. V. Hammer de "renkli haraç kâğıtları” nın bu yılda yapıldığını belirtmiştir. ${ }^{52}$ Renkli varakalar âlâ, evsat ve edna seviyelerine işaret ediyordu. Bu suretle defterin sonunda "toplam" başlığı altında "kırmızı nefer ${ }^{53}$ adet 1.686 " ve "beyaz nefer adet 34 " kaydı düşülmüş olup ${ }^{54}$ bu renkler, cizyegüzârın iktisadi vaziyetine delaletti. Kırmızı ve beyaz renkteki evrakın toplamı 1.720'dir. Oysaki defterdeki tüm cizyegüzârların sayısı 1.576'dır. İki

48 Sa îd ed-Dîveci, Târîhül-Mevsıl, II, s. 160.

49 Bu kavramlar zengin (âlâ), orta halli (evsat) ve fakir (edna) reayayı tanımlamak içindir. Halil İnalcık, "Cizye", Türkiye Diyanet Vakfi İslâm Ansiklopedisi (TDVİA), 1993, VIII, s. 46.

50 Râşid Mehmed Efendi Çelebizâde İsmail Âsım Efendi, Târîh-i Râşid ve zeyli, Abdülkadir Özcan-Yunus Uğur-Baki Çakır-Ahmet Zeki İzgöer (haz.), (İstanbul: Klasik Yayınları, 2013), I, s. 401-402; Anonim Osmanlı Tarihi (1099-1116/1688-1704), Abdülkadir Özcan (haz.), (Ankara: Türk Tarih Kurumu Yayınları, 2000), s.19; Süleyman Sûdî, Osmanlı Vergi Düzeni (Defter-i Muktesid), M. Ali Ünal (haz.), (Isparta: Fakülte Kitabevi, 2008), s. 84.

51 Bir örnek için bkz. Başbakanlık Osmanlı Arşivi (BOA), Bâb-ı Defteri Cizye Muhasebesi (D.CMH) 217/1, 10 Nisan 1690) (Gurre-i Receb 1101).

52 Nedkoff, "Cizye”, s. 634.

53 "Nefer" terimi “cizyegüzâr olan er/erkek kişi”yi tanımlamak için kullanılmıştır.

54 BOA, KK.d, nr. 3813, s. 39. 
sayı arasındaki fark, yani 144 sayısı, devletin verdiği evrakın fazlalığıydı; çünkü kâğıtların miktarları ve sınıfları önceki yılın tecrübelerine ve hazinenin ihtiyacına göre ${ }^{55}$ tahminen belirlenmekteydi.

İncelenen defterde cizyegüzârlara düşen cizye miktarı kaydedilmemiştir. Önceki tarihlere ait cizye miktarlarına dair bilgi mevcuttur. Mesela zimmiler, bahaneler ileri sürerek cizyelerini eksik vermişti. Eyaletteki zimmiler devlet için 3 kuruş, tahsildar için de 1 rub' ödemişti. ${ }^{56}$ Cizyegüzârların medeni halleri de dikkate alınmaktaydı. Baş cizyeleri için her sene evlilerden 1'er kâmil kuruş, bekârlardan 0,5 kuruş alınması emredilmişti. ${ }^{57} 1691$ senesi için de edna olanlardan bir şey talep edilmemişti..$^{58}$

\section{a. Musul'un Yerli Cizyegüzârları}

Musul Kazası'nda toplam cizyegüzârların \% 45,56'sı kaza merkezinde olup çoğu düşük gelirliydi (bkz. Tablo-1). Cizyegüzârların kaza merkezlerindeki oranlarının ortalaması takriben \% 50'ye yakın olduğu ve iktisadi vaziyetlerinin ise müreffeh olmadığı, Trablusşam Eyaleti'ne tabi Hama ve Humus kazalarının cizye defteri örneğinde de görülmüştür. Hama Kazası'nda 513 cizyegüzârın \% 53,61’i, Humus Kazası'nda ise toplam 228 cizyegüzârın \% 44,44'ü kaza merkezlerindeydi. ${ }^{59}$ Hama merkezindekilerin \% 50,55'i evsat, \% 49,45'i edna iken Humus'un merkezinde evsat $\% 50,23$, edna ise $\% 49,77$ idi. $^{60}$

55 Nedkoff, "Cizye”, s. 622.

56 BOA, MAD.d nr. 9834, 18 Haziran 1647, (15 Cemâziye'l-evvel 1057), s. 63.

57 Başbakanlık Osmanlı Arşivi (BOA), Bâb-ı Defteri Başmuhâsebe Kalemi (D. BŞM.d), 184, (4 Muharrem 1060 (7 Ocak 1650), s. 6.

58 Başbakanlık Osmanlı Arşivi (BOA), İbnü’l-Emîn Dâhiliye (İE.DH) 10/980, 23 C 1102 (24 Mart 1691).

59 BOA, MAD.d nr. 3649, s. 3-36 (1102/1690-91).

60 BOA, MAD.d nr. 3649, s. 3-36 (1102/1690-91). 
Tablo 1. Musul Şehrindeki Cizyegüzârların Mahallelere Göre Dağılımı

\begin{tabular}{|c|c|c|c|c|c|}
\hline Mahalle & Toplam Nefer & Âlâ & Evsat & Edna & Belirsiz \\
\hline Dergâh-1 Nestûrî́ ${ }^{61}$ & 215 & 3 & 77 & 134 & 1 \\
\hline Dergâh-1 Ya'kûb & 180 & 2 & 59 & 115 & 4 \\
\hline Kal'a-1 Ya'kûb & 143 & 1 & 59 & 82 & 1 \\
\hline Cemaat-1 Yahudiyân ${ }^{62}$ & 98 & - & 20 & 75 & 3 \\
\hline Kal'a-1 Nestûrî & 82 & - & 25 & 56 & 1 \\
\hline Toplam & 718 & 6 & 240 & 462 & 10 \\
\hline
\end{tabular}

Musul, Hama ve Humus'ta cizyegüzârların sakin oldukları mahalleler dinî kimliklerini yansıtıyordu. Hama'nın merkezindekilerin \% 78,55'i, Humus'un merkezindekilerinse \% 42,86'sı Nasârâ olarak adlandırılan mahalledeydi. Musul'dakilerinse \% 44,99'u Yakubi, \% 41,36's Nesturi ve \% 13,65'i ise Yahudi ismiyle anılan mahallede sakindi. Musul'dakilerin iktisadi vaziyetleri sonraki

61 Musul'da Nesturilerin 1000 kişiye ulaştı̆̆ı, şehrin yakınındaki dağlarda yoğun oldukları, yaklaşık 40.000'e vardıkları ve dağ köylerinde yaşadıkları kaydedilmiştir. Giuseppe di Santa Maria Sebastiani, Rıhletü Sebastiyânî el-Eb Cûzîbe Dî Sântâ Mâriyâ el-Kermelî ilâll-'Irâk senetü 1666 m., Betrus Haddâd (trc.), (Beyrût: ed-Dârü'l-'Arabiyyetü li'l-Mevsûâti, 2006), s. 24. Musul Kazası'nın merkezindeki Nesturiler kastediliyorsa, Dergâh-1 Nestûrî ve Kal'a-1 Nestûrî̀dekilerin tamamının Nesturi olduğu bilinmemekle birlikte, verilen 1000 kişilik değer yaklaşık bir değerdir; çünkü deftere göre her iki mahallede sadece cizyegüzârların sayısı 323 'tür. Bunlara ailelerin de eklenmesiyle yaklaşık değer bulunur; ancak 40.000 sayısı tartışılır.

6231 Ekim 1688 tarihli bir fermanla Musul Kazası'ndaki Yahudilerin tahriri 3 Şubat 1689'da gerçekleştirilmişti. Mardin Şer iyye Sicilleri (MŞS) nr. 248, s. 127, 31 Ekim 1688, (6 Muharrem 1100). İslam beldelerinin bolluk ve müreffeh zamanlarında Yahudilerden, haraç konusunda, noksan talep edilerek kendilerine mühlet tanınmış ve gönülleri bolluğa kavuşturulmuştu. Ancak sonraları taifenin, "emred ve mürâhık” olup haraç vermeye muktedir olanlarıyla birlikte, yeniden tahriri emredilmişti. "Biz maktûa olunmuşuz veyahut haneye bağlıydık" gibi bahanelere karşı da kadılar uyarılmış ve cizyenin "mühimmat-ı seferiye için” hazineye teslimi istenmişti. Kazaya bağlı 'Ayn-1 Safna Köyü reayasından Musul'da bulunan Yahudilerin isimlerini içeren 3 Şubat 1689 tarihli deftere göre kazada sakin Yahudilerin iktisadi vaziyetlerine nazaran yeniden tahriri gerekli görülmüştü. Ancak nefs-i Musul'da "tahrirli” Yahudi olmayıp 'Ayn-1 Safna reayasının Musul dâhilinde olduğu ve “icmâl-i sultânî”de kayıtlı bazı Yahudilerin perakende bazılarının ise Musul'da sakin olduğu tespit edilmiştir. Başbakanlık Osmanlı Arşivi (BOA), 'Alî Emîri Süleyman II (AE.SSÜL. II) 20/2081, 3 Şubat 1689, (12 Rebî́ü'l-âhir 1100). Bu deftere 73 Yahudi kaydedilmişti. Bunlardan 43'ünün isimleri Musul defterinde mevcut olduğu saptanmıştır. BOA, KK.d nr. 3813, s. $15-17$. 
yüzyılda değişmişti. Bir temessükte ${ }^{63} 301$ âlâ, 1988 evsat ve 491 edna olmak üzere toplam 2780 evrak kayıtlıdır. Önceki yüzyılda edna sayısı daha çokken, sonraki yüzyılda evsatın daha fazla olduğu saptanmıştır. İbrenin yönündeki bu değişim çoğu reaya için düşük gelirli statüden orta halli statüye doğru olumlu bir değişimin belirtisi veya hükûmetin vergi gelirlerini arttırmak maksadıyla ortaya koyduğu vergi politikası gibi görünse de şunu da unutmamak gerekir ki cizye varakaların sayısı, tahminen belirlendiğinden tezkerelere dayalı kesin yargılardan kaçınılmalıdır.

\section{b. Farklı Eyaletlerden Musul Kazası'na Gelen Yabancı Cizyegüzârlar}

Musul Şehri üzerinden tüm beldelere gidilebildiğinden "Irak kapısı" ve "Horasan’ın anahtarı" olarak tanımlanan ve doğuya ve batıya gidenlerin sıklıkla uğradığı Musul, ${ }^{64}$ XVII. yüzyılın son çeyreğinde de bu konumunu yitirmemişti. Cizye defterinde "yabancı reaya” yani farklı eyaletlerden Musul Kazası'na gelenler, perakende olarak tanımlanmaktaydı. Münferit belgelerdeyse sıklıkla "perişan" kelimesiyle de birlikte kullanılan perakende, "dağılmış" veya "kayıtlı olduğu idari birimden ayrılmış" reayaya işaretti. Cizye defterlerinde perakendeler iki şekilde sınıflandırılıyordu: Çalışan perakendeler ve gelip-giden perakendeler. ${ }^{65}$ Birincisi, tuttuğu işten dolayı şehirdeki ikametleri cizye tahririnden önce başlayıp tahrir sonrasında da devam edenlere, ikincisi ise o vakit tahrir esnasında orada geçici olarak bulunanlara yani “âyende ve revende (gelip-giden)"ye delalettir. Musul'un merkezinde, yerli ve yabancı olarak, 841 cizyegüzârın 133'ü perakendeydi. Bunların 123'ü "defter-i perâkende-i der-müsâferet-i Musul" başlığı altında verilirken ${ }^{66}$ (43 cizyegüzârdan ${ }^{67}$ ) 10'u perakende olarak yerliler arasında kayıtlıdır. 10 cizyegüzârın 1'i Dergâh-1 Nestûrîde, 9'u Yahudi mahallesindeydi: Bunlardan 4'ü Mardin'den, ${ }^{68} 1^{\prime} \mathrm{i}$ İmadiye'den, ${ }^{69}{ }^{9}{ }^{\prime} \mathrm{i}$

63 Başbakanlık Osmanlı Arşivi (BOA), Cevdet Maliye (C.ML) 448/26539, 7 Şubat 1772, (3 Zi'l-ka'ade 1185).

64 Eş-Şeyhü’l-İmâm Şihâbeddin Ebî Abdullah Yâkût bin Abdullah el-Hamevî er-Rûmî elBağdâdî, Mu'cemül-Büldân, (Beyrût: Dârü Sâdır, 1397/1977),V, s. 223.

65 Antakya'da perakendeler "işleyan” ve "gelub gidan” diye sınıflandırılmıştır. bkz. BOA, D.CMH, 26681, s. 14 (1106/1694-95).

66 BOA, KK.d, 3813, s. 35-39.

67 Musul Kazası'nın genelinde yerli cizyegüzârlar arasındaki perakendelerin toplamını göstermektedir.

68 3'ü Hatun Köyü'nden, 1'i Bâb-1 Cedîd Mahallesi'ndendi.

69 El-İmâdiyye, Musul'un kuzeyinde bir kaledir. el-Hamevî, Mu'cemül-Büldân, IV, s. 149. Musul'un $80 \mathrm{~km}$. kuzeyinde olup Yahudi ve Keldanilerin de yaşadığı bir kasabadır. Sami, Kâmûsül-Â'lâm, V, s. 3206. 
Bağdat'tan, 2'si Halep'ten ve 1'i Diyarbakır'dan gelen yabancılardı. ${ }^{70} 123$ perakende içinde Mardin 16, Diyarbakır 13, Bağdat 9, Cıska 7, Halep 3, Tokat 3, Üsküdar

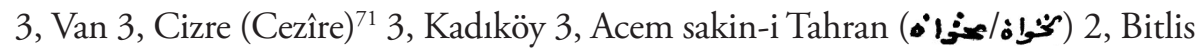
2, Urfa 1, Rûhâ 1, Ahıska 1, Erzurum 1, İstanbul 1, Kilis 1, perakende-i Musul

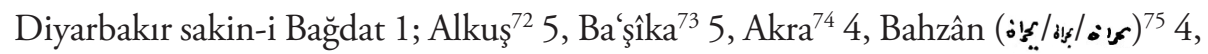
Bartalla $^{76}$ 4, Karakuşs 4 , Tel' 'afer 4, Kermelîs ${ }^{78}$ 3, Nestûrî (Mahallesi) 2, Bâşbeyte 1,

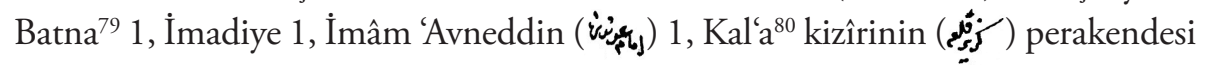

70 Diyarbakır merkezine bağlı mahalle ve köylerdeki bazı cizyegüzârların ticaret ve zanaat sebebiyle Musul'a gittiklerini gösteren ve 1102/1690-91 yılına ait Maliyeden Müdevver Defterler tasnifinin 21812 numaralı cizye defteri çürük olduğu için dijital ortama aktarılmadığından ulaşılamamıştır.

71 Cezîre-i İbn-i Ömer olarak da bilinen Cizre, Musul'un yukarısında (kuzeyinde) bir belde olup Musul ile arası üç günlüktü. el-Hamevî, Mu'cemüll-Büldân, II, s. 138.

72 Ahalisi Hristiyan olan bu köy Alkuş Dağı'nın eteğinde kurulmuştur, Musul'a bir buçuk konak uzaklığındaydı. Yâsîn el-Ömerî, Meniyyetüll-udebầ, s. 128.

73 Bâ'şîkâ/Ba'şîka, Dicle’nin doğusundaydı. İçinde hamamların ve bezin satıldığı bir kaysâriyyenin bulunduğu büyük bir çarşıya sahipti. Ahalisinin çoğunluğu Hristiyan olsa da köyde büyük bir cami vardı. Ba'şîka ile Musul arası 3/4 fersahtı. Bu köyün yakınında çarşıları olan büyük bir köyün varlığı aslında el-Hamevî zamanında Ba'şîka ve çevresinin üretici-tüketici için cazip bir konumda olduğuna işarettir. el-Hamevî, Mu'cemül-Büldân, I, s. 324-325.

74 Çelebi zamanında bu köy de bir pazar yeriydi. Evliya Çelebi, Seyâhatnâme (III. ve IV), s. 375b. 1630'da Akra'da Nesturiler yaşıyordu. Rafầîl, Târîhü Nasârâül-'Irâk, s. 132.

75 Bahzân/Bâhzânî, Ba şîka’nın yakınındaydı. Yâsîn el-Ömerî, Meniyyetül-udebâ’, s. 134.

76 “Şehir gibi bir köy” olarak da tanımlanan ve çarşıları olan Bertullâ/Bartalla (بَرطُّلى aynı zamanda paranın döndüğü bir yerdi. Halkı çoğunlukla Hristiyan olmakla birlikte Müslüman cemaate ait bir cami bulunuyordu. el-Hamevî, Mu'cemül-Büldân, I, s. 385.

77 Ahalisi Hristiyan olan Karakuş büyük bir köy olup Musul'dan bir konak uzaklıktaydı. Yâsîn el-Ömerî, Meniyyetül-udebâ', s. 160.

78 Muhtemelen mamur bir çarşısı ve tüccarın varlığından dolayı köy el-Hamevî̀ye göre şehri andırmaktaydı. El-Hamevî, Mu'cemü̉l-Büldân, IV, s. 456. Köydeki tüccarın varlığı ise Kermelîs'in anayol (tarîk-i câdde) üzerinde bulunmasından kaynaklanıyordu. Köyün konumu, reayasının perakende olmasına da sebep olmuştu. 25 Nisan 1707'de 123.000 akçe yazısı olan Kermelîs, otuz sene boyunca yıllık sadece 20.000 akçeye fürûht olunuyordu. Köyün bayındır kılınması için yıllık 31.000 akçe verilmesi koşuluyla malikâne üzere deruhte edilmişti. Başbakanlık Osmanlı Arşivi (BOA), Tahrir Defterleri (TD.d), nr. 1109, s. 8 (22 M 1109/10 Ağustos 1697).

79 Bâtnâ, Bâtna ve Bâtnâyâ olarak da geçen köy, mamur olup ahalisi Hristiyandı ve Musul'a yarım konak uzaklıktaydı. Yâsîn el-Ömerî, Meniyyetü'-udebâ', s. 133.

$80 \mathrm{Kal}^{‘} \mathrm{a}-1$ Ya'kûb mu yoksa Kal'a-1 Nestûrî mi olduğu bilinmemektedir. 
1, yine kizîr ${ }^{81}$ perakendesi 1 , Tellkeyf ${ }^{82} 1$, Tell Üsküf ${ }^{33} 1$, Ya'kûb (Mahallesi) 1 cizyegüzâra sahipken 5 'inin memleketi kaydedilmemiştir. Hama'nın merkezinde ise yabancıların sayısı 4'tür, 3'ü Halep'ten 1'i Şam'dandı. ${ }^{84}$ Humus'un merkezinde tamamı 11 olan yabanciların 4’ü Hama’dan, 3’ü Halep’ten, 2’si Kayseriden ve diğerleri ise Şam ve Diyarbakır'dandı (Cıska) ${ }^{85}$ Hama ve Humus'taki yabancıların çoğunluğu Halep’tendi.

Yabancıların bölgesel kimliklerinden, Musul Kazası'na yönelik nüfus hareketlerinin dört yönde olduğu anlaşılıyor: Birincisi farklı kentler ve bu kentlerin çevrelerinden Musul'un kaza merkezine doğru gerçekleşen hareketler olup nüfus hareketlerinin \% 60,90'ını oluşturuyordu (bkz. Tablo-3). Bu hareket türü, daha çok Selçuklu Türkiye’si devrindeki transit ticaret kervanlarının Antalya ve Alaiye'den İran ve Gürcistan'a doğru giden ana yol üzerindeki Sivas'tan saparak Güneydoğu’ya doğru takip ettiği -ki Basra’ya kadar uzanır- hat ${ }^{86}$ üzerinde bulunan Diyarbakır-Mardin-Musul-Bağdat gibi şehirlerin güzergâhında gerçekleşmişti. Diğer güzergâh ise İstanbul'dan Mısır'a giden kervanların Şam'a niyetlenmeden Halep’en doğuya kıvrılan koldaki Kilis-Nusaybin-Musul-Bağdat çizgisindeydi. Nitekim Halep'ten Musul'a ticaret kafilesi gelmekteydi. ${ }^{87}$ İstanbul hariç tutulursa, yabancıların geldiği şehirler arasında Tokat ve Halep en batıdaki şehirlerdi. Ancak yabancılar arasında Doğu Akdeniz kentlerinden ve Şam'dan tek bir cizyegüzâr dahi yoktu. Muhtemelen bu, tahrir esnasında Musul'da bulunmamalarından kaynaklanıyordu. Çünkü Şam'dakilerin Musul'dakilerle bir bağlantısı vardı. Mesela Seyyah İlyas Hanna el-Mevsılî öncesinde Şam'da yaşamış olup burada akrabaları bulunuyordu. ${ }^{88}$ Diğer taraftan bu, cizyegüzârlar açısından Halep'in, Musul ile Şam, Sayda ve Trablusşam arasında ticari bağlantı sağlayan bir kent işlevi

81 Hangi mahalle kizîri olduğu belli değildir.

82 Büyük bayındır bir köy olup halkı Hristiyan olan Tellkeyf, Peygamber Cercis'in vakfıydı.

Yâsîn el-Ömerî, Meniyyetü'l-udebâ', s. 139.

83 Dicle’nin doğusunda büyük bir köydü. el-Hamevî, Mu'cemü'l-Büldân, II, s. 39. Ahalisi zengin Hristiyanlardan oluşuyordu. Yâsîn el-Ömerî, Meniyyetüll-udebầ, s. 137.

84 BOA, MAD.d, 3649, s. 29, 30, 33, 34 (1102/1690-91).

85 BOA, MAD.d, 3649, s. 9, 10, 11, 12, 34, 36 (1102/1690-91).

86 Mustafa Akdağ, Türkiyénin İktisadî ve İçtimaî Tarihi 1 (1243-1453) (İstanbul: Cem Yayınevi, 1995), I, s. 30; Ahmet Tabakoğlu, Türk İktisat Tarihi (İstanbul: Dergâh Yayınları, 1997), s. 114.

87 BOA, A.DVNS.MHM.d, 36, 47/142 1 Şubat 1579 (4 Zi’l-hicce 986).

88 İlyas Hanna, İlyas Hanna Seyahatnamesi, Bir Osmanl Tebaasının Güney Afrika Yolculuğu, 1668-1683, çev. Bekir Keskin, (İstanbul: Kitap Yayınevi, 2010), s. 19. 
gördüğüne delildir. ${ }^{89}$ Nitekim "Bilâdüş’Şam’ın anahtarı" ${ }^{90}$ olarak bilinen Halep, Şam, Musul, Hama ve Humus kazaları arasında XVII. yüzyılın son çeyreğinde en fazla cizyegüzâr barındıran şehirdi. ${ }^{91}$

Farklı kentlerden yapılan nüfus hareketleri, takriben Halep-Kilis-Tokat hattının doğusundaki bölgelerden gerçekleşmişti. Bu hareketlerin çıkış noktalarının \% 39,85’i bugünkü Doğu ve Güneydoğu Anadolu sınırları içindeydi. Kuzeyde Tokat güneyde Halep, gezgin ve tacirlerin kesişme noktalarıydı ve Doğuya kıvrılan yolların en önemlileri bu iki şehir üzerinden Musul'a geçmekteydi; Simeon, Tavernier ve Tournefort Tokat'in Doğu'nun "en mühim" kesişme noktalarından ve "Küçük Asya'nın ticaret merkezi" olduğunu kaydetmiştir. ${ }^{92}$ Aynı zamanda Tokat ordu için, Bağdat'a uzanan askerî bir güzergâhtı. ${ }^{93}$ Bir kervan için Musul-Tokat arası bir ay sürmekte, Musul'dan gelen kervanın Tokat'a bez, boyalı tülbent ve palamut taşıdığı, önceleri Hintli ve İranlı tacirlerin Musul üzerinden Tokat'a gittikleri, ancak bunun uzun zaman kesintiye uğradığı belirtilmiştir. ${ }^{94}$ Tokat, Musul'daki ticari emtianın, kapamacılar esnafının Musul bezleriyle dükkânlarını süslediğiis İstanbul'a götürüldüğü güzergâhtaydı. Halepli, Musullu, Diyarbakırlı, Üsküdarlı, Karamanlı bazı Müslüman tacirler beraberindeki tüccarla İstanbul'da oturmaktaydı. Öyle anlaşılıyor ki bunlar Bağdat, Basra, Diyarbakır, Musul, Halep, Tokat ve diğer yerlerden İstanbul'a veya ötesine ticari mal taşıyordu. Buralardan mal alıp batıya nakletmeleri, bu şehirlerin ihracat merkezi veya antrepo kent konumunda olduğunu gösteriyor. ${ }^{96} \mathrm{O}$ hal-

89 Ne yazık ki Halep cizye defteri, cizyegüzârların mesleklerini içermemektedir. Ayrıca defterdeki cizyegüzârlar, yerli ve perakende olarak sınıflandırılmamıştır. BOA, MAD.d, nr. 1215, s. 4-38 (1103/1691-92).

90 Ed-Dîveci, Târîhül-Mevsıl, II, s. 117.

91 Halep için bkz. BOA, MAD.d, nr. 1215 (1103/1691-92), s. 4-38; Şam için bkz. Oğuzhan Samıkıran, "Nefs-i Şam Örneğinde Gayrimüslimlerin Nüfus ve Mesleklerine Dair Bir Araştırma”, Avrasya İncelemeleri Dergisi (AVID), III/2 (2014), s. 233; Hama ve Humus için bkz. BOA, MAD.d, nr. 3649, s. 3-36 (1102/1690-91).

92 Hrand Der Andreasyan, Polonyalı Simeon'un Seyahatnâmesi (1608-1619), (İstanbul: Everest Yayınları, 2013), s. 210; Tavernier, Tavernier Seyahatnamesi, s. 53; Tournefort, Tournefort Seyahatnamesi, II, s. 223.

93 Der Andreasyan, Simeon'un Seyahatnâmesi, s. 210; Tavernier, Tavernier Seyahatnamesi, s. 53. 94 Der Andreasyan, Simeon'un Seyahatnâmesi, s. 213.

95 Evliya Çelebi, Seyâhatnâme (I. ve II), s. 192a.

96 “...kadîmü’l-eyyâmdan (beri) Bağdad ve Basra ve Diyarbekir ve Musul ve Haleb ve Tokad ve gayri yerlerden metâc alub denk bağlayub doğru İstanbul'a gelub...”. BOA, AE.SAMD. II 20/2171, 22 Aralık 1693 (23 Rebî‘ül-âhir 1105). 
de Musul'daki yabancıların amaçlarından biri, Musul'un ticari imkânlarından ve ticaretin yarattığı istihdam alanlarından yararlanmaktı. Ticari malların çıkış noktası Basra olduğu düşünülürse, Basra’dan batıya doğru ilerledikçe bu malların, nakliye ve diğer masraflardan dolayı, kıymetleri sabit kalmayacaktı. Nitekim tüccar, Hindistan'dan Basra'ya gelen malları almak için bu kentte toplanıyor ve mallarını yine Basra'da satın aldıkları develere yüklüyordu. ${ }^{97}$ İlgili hükümde eskiden Hint, Acem, Bağdat, Basra, Musul, Diyarbakır, Erzurum, Halep, Şam, Tokat ve Anadolu'dan doğrudan İstanbul'a gelmesi gereken tüccar kafilelerinin 1664-65'te Tokat'tan Karadeniz taraflarına yönelmeleri hem tüccar hem de gümrüksüz geçtiklerinden devlet aleyhineydi. Acem Ermenileri ile samurcu zimmiler, tüccarın satın aldıkları benzer malları alıp İstanbul'a uğramadan Karadeniz ve Rumeli üzerinden Tuna’ya oradan Eflak ve Boğdan'a kaçırarak, perakende olarak, satmaktaydı. Bu durum, Müslüman tüccarın -keza Musullu tüccarın- mallarına rağbeti azaltarak onları zarara uğrattı̆̆ından İstanbul gümrüğü eminince Tokat'ta bir memurun oturtulmasına hükmedilmişti. Memur, Rumeli'ye gitmek için Tokat'a gelen tüccarın yüklerini açtırmadan ve sattırmadan bu yüklerin İstanbul'da açılarak satılmasını sağlayacaktı. Bu karar, Doğu mallarının ticaretini yapan Musul'un ve diğer kentlerdeki tüccarın haklarının korunduğuna ve kısmen Doğu-Batı ticaretini kontrol etme noktasında Tokat' in bir tür ticari karakol olduğuna işaretti.

Nüfus hareketlerinin ikinci yönü Musul'un kırsalından merkezine doğru hareketler olup \% 28,57 oranına sahipti. Ü̧üncüsü ise şehir içi hareketlere misal teşkil etmektedir ki nispeti \% 5,26 idi. Bölgesel kimliği kaydedilmeyenlerin oranı ise \% 4,51'di. Kaza merkezine yönelik nüfus hareketlerinin çıkış noktalarına göre ilk sırayı Mardin, akabinde Diyarbakır ve Bağdat almaktaydı; 133 yabancının \% 15,04'ü Mardin'den, \% 10,53'ü Diyarbakır'dan, \% 8,27'si Bağdat'tan ve \% 5,26'sı İstanbul ve çevresinden yine \% 5,26's1 Ciska'dan ve \% 3,76's Halep'tendi. Halep, Musul için "Bâbüsş-Şam" konumunda olmasına rağmen, ${ }^{98}$ Halep perakendeleri Musul'da daha azdı; çünkü Halep cizyegüzârları, Musul'a ihtiyaç duymadan, ihtiyaçlarını Halep’ten karşılama imkânına sahipti. Hatta Halepli cizyegüzârların daha çok Cebele, ${ }^{99}$ Trablusşam merkezi ${ }^{100}$ ve Trablusşam İskelesi ${ }^{101}$ ile münasebet-

97 Tavernier, Tavernier Seyahatnamesi, s. 247.

98 Ed-Dîveci, Târîhü̈l-Mevsıl, II, s. 117.

99 Başbakanlık Osmanlı Arşivi (BOA), (KK.d, nr. 3820, s. 5.

100 BOA, KK.d nr. 3820, s. 11, 12.

101 BOA, KK.d nr. 3820, s. 23, 24, 25. 
leri vardı. Musul'un merkezindeki yabancıların oranı \% 15,81'di. Buna karşılık yine aynı dönemde Şam Kazası'nın merkezinde ise toplam 2.424 cizyegüzârın sadece 77 'si ${ }^{102}$ yani $\% 3,18$ 'i yabancıydı. Bu değerlerden, Musul'daki yabancıların, şehirdeki cizyegüzârların yaklaşık 1/6'ine denk gelirken, Şam'daki bu değer yaklaşık 1/31'di.

Hareketleri tespit etmek mümkünken bunların sebepleri konusunda, meslekleri bilinse dahi kesin yargilar ortaya atmak mümkün gözükmüyor ve perakende oldukları tarihler de bilinmiyor. Ancak Musul'da perakendesi en fazla olan Mardin'in zimmilerinin yaşadığı bazı mahalle ve köyler, XVI. yüzyılın sonlarında da perakende ve perişan bir vaziyetteydi. ${ }^{103} 1598$ 'de, Mardin'in Kuseys Mahallesi ${ }^{104}$ ile Güleli ${ }^{105}$ ve Mansûriye ${ }^{106}$ köylerinin cizyegüzârları perakende olmuştu. Mansûriye'de 176 cizyegüzâr sakindi, ancak bunlardan bazıları yine perakendeydi. ${ }^{107} \mathrm{Ne}$ yazık ki bunların Musul'a mı yoksa farklı bölgelere mi dağıldıkları bilinmemektedir.

Diyarbakır ve çevresinin de XVII. yüzyılın ikinci yarısındaki vaziyeti aynıydı; Tercil'e bağlı Şeddâd ve Ebu'l-Vefâ köyleriyle Ergani'ye bağlı Solâk ve Herçelik köyleri uzun zamandan beri, ${ }^{108}$ Amid'e bağlı Gâzî/Tîl Gâzî Köyü ise birkaç seneden beri ${ }^{109}$ boş (hâlî) ve haraptı. Yine Amid'e bağlı Ak Hüseyin ve Karalı köyleri ${ }^{110}$ ile Savur'da Saaddedinlü Köyü de boş ve haraptı. ${ }^{111}$ Hükümlerde cizyegüzârları olumsuz etkileyen sebeplere de rastlanmışır. Mesela cizyedarlar, Cıska zimmilerinden her yıl fazla para talep etmişti. ${ }^{12}$ Diyarbakır'da Kara ve Kızıl Tamgâ Mukataası' na bağlı esnaftan valilerle mütesellimlerin "uzun-kısa/kısa akçesi” adında akçe talebi esnafin tamamen perakende olmasına neden olmuştu. ${ }^{113}$ Ergani'de

102 Şam eyaletindeki cizyegüzârların takriben \% 54’ü Şam’ın merkezinde kayıtlıydı. Samıkıran,

"Nefs-i Şam", s. 223, 233.

103 MŞS, 259, (15 Zi'l-ka'de 1006/19 Haziran 1598), s. 165, 166 (16 Zi'l-ka'de 1006/20 Haziran 1598), 180, 181 (19 Zi'l-ka'de 1006/23 Haziran 1598).

104 MŞS, nr. 259, 20 Haziran 1598 (16 Zi'l-ka'de 1006), s. 180.

105 MŞS, nr. 25919 Haziran 1598, (15 Zi’l-ka‘de 1006), s. 165.

106 MŞS, nr. 259, 21 Zi'l-ka'de 1006 (25 Haziran 1598), s. 181.

107 MŞS, nr. 248, 29 Kasım 1689, (16 Safer 1101), s. 46.

108 BOA, MAD.d nr. 2742, 16 Kasım 1665 (8 Cemâziye'l-Evvel 1076), s. 39.

109 BOA, MAD.d nr. 2742, 12 Mayıs 1666 (8 Zi'l-ka'de 1076), s. 114.

110 BOA, MAD.d nr. 2742, 24 Şubat 1667 (29 Şa ‘bân 1077), s. 171.

111 BOA, MAD.d nr. 2742, 19 Nisan 1667 (24 Şevvâl 1077), s. 194.

112 BOA, MAD.d nr. 2931, 3 Kasım 1685 (6 Zi'l-hicce 1095), s. 317.

113 BOA, MAD.d nr. 2935, 16 Kasım 1687 (10 Muharrem 1099), s. 9, 10. 
Sakardiğin Köyü önceleri boş ve harap iken şen ve abadan edilmiş, fakat tekrar boş kalmıştı. ${ }^{14}$ Çaruği Köyü de nice zaman boş ve harapt1, ancak -muhtemelen 1670'lerin sonlarından itibaren- on yıldır tasarruf ediliyordu. ${ }^{15}$ Sonraki yıllarda Diyarbakır'da Şeyh Davud Köyü de boşalarak harabeye dönmüștü. ${ }^{116}$

Bağdat'ın ahvali de kötüydü. Bağdat-Musul-Diyarbakır güzergâhı eşkıyadan dolayı her zaman güvenli değildi. Bağdat tarafından Diyarbakır'a gelmek isteyen tüccar eşkiyadan korkuyordu. ${ }^{117}$ Ayrıca 1688'de Dicle ve Fırat suyunun çekilmesi, ${ }^{118} 1689$ 'da kıtlık, taun, pahalılık ve kuraklık ölümleri ve göçü tetiklemişti. ${ }^{119} 1690$ 'da tekrar hortlayan taunun zayiatı önceki salgına göre oldukça büyüktü. Nüfusu azaltmakla kalmamış, çöl Araplarının yağmalarını da kolaylaştırmıştı. ${ }^{120}$ Bağdat havalisindeki Arap eşkıyasının izalesi için Diyarbakır valisinden yardım istenmişti. ${ }^{121}$ Arap eşkıyası birkaç yıl boyunca Basra ve çevresini yağmalamıştı ve Basra Kalesi'ni kuşatıp Basra-Kûrne arası seyahatin kesilmesine ve güney yollarında asayişsizliğe sebep olmuştu. ${ }^{122} \mathrm{Bu}$ muhasaranın, Basra’dan Musul'a farklı amaçlarla yapılacak ziyaretleri engellemiş olması muhtemeldir.

Musul'un ticaret yolu güzergâhındaki Tokat'ta da nüfus hareketleri görülmüştür. Tokat'taki çoğu zimminin perakende olup başka sancak ve kazalarda sakin olmaları üzerine, bulundukları yerde cizyelerinin tahsili emredilmişti. ${ }^{123}$

Bu çalışmada yabancıların Musul'a geliş sebepleriyle bunların Musul'a seyahatlerini engelleyen muhtemel sebepler üzerinde durulmuştur. Ancak Musul'dan farklı amaçlarla başka vilayetlere gidenlerden bahsedilmemiştir. Ölümlerle

114 BOA, MAD.d nr. 2935, 19 Aralık 1687 (13 S 1099), s. 56-57.

115 BOA, MAD.d nr. 2935, 5 Ocak 1688 (Gurre-i Rebîü̉l-evvel 1099), s. 85.

116 BOA, MAD.d nr. 2467, 7 Temmuz 1699), (9 Muharrem 1111), s. 7.

117 BOA, MAD.d nr. 2931, 3 Aralık 1684, (25 Zi'l-hicce 1095), s. 323.

118 'Abbâs el-'Azzâvî el-Mahâmî, Mevsî'atü târîhi'l-'Trâk beyne ihtilâleyni'l-'ahdi'l-'Osmânî essânî h. 1048 - m. 1638/h. 1163 - m. 1750, V, (Basım yeri yok: ed-Dârü'l-'Arabiyyetü li'lMevsû âti, tarihsiz), s. 148.

119 el-'Azzâvî, Târîhi'l-'Trâk, V, s. 150-151.

120 el-'Azzâvî, Târîhi'l-'Trâk, V, s. 153.

121 Başbakanlık Osmanlı Arşivi (BOA), Mühimme Defterleri (A.DVNS.MHM.d), 104, 54/225 (Evâsıt-1 Şevvâl 1103/26 Haziran-5 Temmuz 1692).

122 BOA, A.DVNS.MHM.d, 104, 106/474, $107 / 498$ (Evâsıt-1 Rebî‘ü'l-âhir 1104/20-29 Aralık 1692). Ayrıca bkz. BOA, A.DVNS.MHM.d nr. 104, 169/768 (Evâhir-i Cemâziye'l-âhir 1104/27 Şubat-7 Mart 1693).

123 BOA, D.CMH 219/52 3 Ağustos 1690 (27 Şevval 1101). 
birlikte çeşitli sebeplerden dolayı geçici veya sürekli olarak Musul'u terk edenler de vard. Mesela 1651'de dört ay süren tehlikeli bir taun Musul'da ciddi insan kayıplarına sebep olmuş ve günde binden fazla insan hayatını kaybetmişti. ${ }^{124}$ 1672'de pahalılık, ${ }^{125} 1084 / 1673-74$ 'te ve $1087 / 1676-77^{\prime}$ de $^{126}$ Necid çekirgesinin musallatı ve büyük taun, ${ }^{127} 1099 / 1687-88$ 'de yine büyük bir pahalılığın başlayarak 1688 'de artması, ${ }^{128} 1689$ 'da reayanın yerini yurdunu terk ettiren kıtlık ve yine $\operatorname{taun}^{129}$ Musul merkezinin ve kırsalının toplumsal ve iktisadi hayatını olumsuz etkilemişti. Cizye tahririnden sonra, 1114/1702-3'te, dört ay süren taun Musul Şehri'nde günde binden fazla can almışt1. ${ }^{130} 1711$ 'de Musul ve çevresinde meydana gelen açlık ve pahalılık da sonunda çoğu insanı göç ettirmişti. ${ }^{131}$

\section{Musul Kazası'nın Köylerindeki Yerli ve Yabancı Cizyegüzârlar}

Musul Kazası cizye defterine göre kırsal kesimdeki cizyegüzârların gelir düzeyinin şehre nazaran daha düşük olması (bkz. Tablo-1, 2), Musul'un art bölgesindeki Hristiyan nüfusun XVII. yüzyıl boyunca önemli ölçüde düştüğ ${ }^{132}$ iddiasını desteklemektedir.

Cizyegüzârlara dair kırsal alanların genel durumunu açıklamak açısından bir kıyaslama yapmak gerekirse, Trablusşam’a bağlı bazı kazaların kırsalındaki cizyegüzârların iktisadi şartlarının Musul'dan pek farklı olmadığı göze çarpmaktadır. Musul kırsalındaki düşük gelirlilerin oranı \% 77,41 iken Hama kırsalında bu oran $\% 70,09$, Humus'taysa $\% 90,91$ olduğu saptanmıştır. ${ }^{133}$

124 Câsim Muhammed Hasan el-'Udûl, “el-Kevârisü ve'l-zavâhirü’t-tabî‘ iyyetü fi'l-Mevsıl min hilâli mü’ellifâti'l-mü'errihi'l-Mevsılî Yâsîn bin Hayrullah el-Hatîb el-Ömerî”, Dırâsâtü Mevsıliyyetü, 13 (2006), s. 6.

125 el-'Azzâvî, Târîhi'l-'Trâk, V, s. 123.

126 Yâsîn el-Ömerî, Meniyyetül-udebâ', s. 175.

127 el-'Azzâvî, Târîhi'l-'Trâk, V, s. 125.

128 el-'Azzâvî, Târîhi'l-'Trâk, V, s. 149.

129 el-'Azzâvî, Târîhi'l-'Irâk, V, s. 150-151.

130 el-'Udûl, "el-Kevâris”, s. 7.

131 Süleymân Sầiğ el-Mevsılî,, Târîhbül-Mevsıl, el-cüz'ü’l-evvelü, (Mısır: el-Matba'atü’s-Selefiyyetü, tarihsiz), s. 271; Besim Darkot, "Musul”, İslâm Ansiklopedisi (İA), 1979, VIII, s. 744.

132 Bruce Masters, Christians and Jews in the Ottoman Arab World: The Roots of Sectarianism (Cambridge: Cambridge University Press, 2001), s. 47.

133 Hama merkezindeki cizyegüzârların oranı \% 53,61 iken kırsal alanda bu \% 46,39'a düşmüştür. Kır ile kent arasındaki farkın en yüksek olduğu Humus Kazası'nın merkezi \% 
Tablo 2. Musul Kazası'nın Köylerindeki Cizyegüzârların Dağılımı

\begin{tabular}{|l|c|c|c|c|c|}
\hline Köyler & Toplam Nefer & Âlâ & Evsat & Edna & Belirsiz \\
\hline Tellkeyf & 230 & 1 & 74 & 152 & 3 \\
\hline Karakuş & 228 & 4 & 36 & 187 & 1 \\
\hline Alkuş $^{134}$ & 82 & 3 & 18 & 61 & - \\
\hline Kermelîs & 43 & - & 5 & 37 & 1 \\
\hline Bartalla & 43 & - & 3 & 40 & - \\
\hline Ba'şîka $^{\text {Batna }}{ }^{135}$ & 29 & - & 4 & 24 & 1 \\
\hline Tellkeyf Perakendesi & 27 & - & 8 & 19 & - \\
\hline Tell Üsküf & 21 & - & - & 21 & - \\
\hline Bâş̧beyte Perakendesi & 17 & - & 2 & 14 & 1 \\
\hline Toplam & 15 & - & 1 & 14 & - \\
\hline
\end{tabular}

Tellkeyf perakendesi ve Bâşbeyte perakendesi ibarelerinin maksadı tam olarak anlaşılamamıştır (bkz. Tablo-2). Çünkü “Tellkeyf perakendesi”nden Tellkeyf'i terk eden reaya mı anlaşılmalı, aksine başka bir köyden veya mezradan ayrılıp Tellkeyf'te veyahut Tellkeyf'e yakın bir arazide konaklayan bir topluluk mu anlaşılmalıdır? Kırsal alana dağılmış bu reayanın durumu, şehirlerdeki "müteferrik (ayrılmış, dağınık, parçalı) mahalleler”e benzer bir statüyü çağrıştırmaktadır. Reayası fakir olan Tellkeyf, Hz. Cercis en-Nebî Evkafı köylerinden olup çevresinde kayıtlı köy olmamakla birlikte yolcuların geçidi üzerinde bulunan bir köydü. Hatta sularını dahi üç saatlik yoldan getirmekteydi. Maktu ${ }^{137}$ olan

95,18, kırsalı ise \% 4,82 oranında cizyegüzâr ihtiva ediyordu. BOA, MAD.d nr. 3649, s. 3-36 (1102/1690-91). Hama ve Humus havalisinde bazı köylerin ahalisi zulüm, vergilerin çokluğu ve Arap eşkıyasının istilalarıyla dağılmış ve arazileri boş kalmışı. BOA, A.DVNS. MHM.d nr. 102, 79/358 22 Kasım-1 Aralık 1691 (Evầil-i Rebî́ü’l-evvel 1103).

134 1747'de bu köyde Katoliklerden 100 aile sakindi. Rafầîl, Târîhü Nasâräül-'Trâk, s. 130.

135 Rafầ̂̀l, Batna/Bâtnâyầda 1747 yılında 200 Katolik ailenin olduğunu kaydetmiştir. Rafầîl, Târîhü Nasâräül-'Trâk, s. 130. Cizye defterindeki sayı (sadece cizyegüzâr) ile Rafầîl'in verdiği sayı (cizyegüzâr olmayan aile efradı da dâhil) arasında çok önemli bir fark var.

136 Oysaki Kamil Kepeci'nin 3813 nolu defterine dayanılarak 1691'de Hristiyan nüfusunun sayıldığını ve kırsaldaki yetişkin erkek sayısının 754 olduğunu ileri sürülmüştür. Khoury, Devlet ve Taşra Toplumu, 1540-1834, s.47.

137 Maktu, reayadan tahsil edilecek cizye miktarının önceden kararlaştırılması anlamına gelmektedir. Mehmet Genç, "Mukâtaa", Türkiye Diyanet Vakfi İlâm Ansiklopedisi (TDVIA), 2006, XXXI, s. 129. 
12.512 akçe cizyelerini her yıl vakfa ödemelerine rağmen, cizyedarlarca mağdur edilmekteydi ve eşkıyadan dolayı çoğu reayası köylerini terk etmişti. Âlâ, evsat ve edna olarak cizyelerini ödeyemeyen reaya, yine eskisi gibi maktu veya deftere göre (yani mühürlü ve nişanlı defter gereğince hane üzerinden) veyahut en düşük miktarla (edna) ödemeyi dilemişti. ${ }^{138}$ Bunlara rağmen XVIII. yüzyılın ortalarına gelindiğinde, 1747 'de, Tellkeyf'te toplam 150 Katolik aile mevcuttu. ${ }^{139}$ Bâşbeyte Köyü’ne dair geçen tek kayıt ise "Bâşbeyte Köyü perakendeleri” idi. Bu, Bâşbeyte'deki cizyegüzârların tamamının dağıldığına işarettir.

Yukarıda Musul'un merkezine yönelik üç çeşit nüfus hareketinden bahsedilmişti. Dördüncü hareket türü ise Musul'un kırsal alanları arasındaydı. Bu hareketin failleri, yerliler arasına kaydedilen yabancılar olup Tellkeyf, Karakuş, Kermelîs, Ba'şîka, Tell Üsküf, Batna ve Alkuş'ta perakende olarak kaydedilen 33 neferden oluşuyordu. ${ }^{140}$ Tellkeyf'te 4 neferin (edna) 2'si Behendivâ Köyü’nden, diğer 2'si ise Bâkûfa Köyü'ndendi. ${ }^{141}$ Karakuş'taki 15 perakendeden (14'ü edna) sadece 1'i Mardinliydi. Keremlîste 3; ${ }^{142}$ Ba'şîka'da 4; ${ }^{143}$ Tell Üsküf'e Bahzân Köyü’nden gelen 1 perakende kayıtlıydı. Batna’da $2^{144}$ ve son olarak Alkuş'taysa 4 perakende $^{145}$ sakindi. Bu reayanın çevreye dağılma sebeplerine dair bir belgeye rastlanmamıştır; ancak XVII. yüzyılın ilk yarısında Musul'un köylerinde çaresizlik, baskı ve saldırılardan dolayı göç olduğu kayıtlıdır. Bu yüzden devlet, serhat bölgesini ıslah maksadıyla vergileri üç aya kadar affetme kararı almıştı. ${ }^{146}$ Ba'şîka, Orta Harâb Mezrası ve bazı yerler mamur kılınması için ulemaya tevcih edilmişti. ${ }^{147}$

138 BOA, KK.d nr. 3509, 21 Temmuz 1695 (9 Zi'l-hicce 1106), s. 124.

139 Rafầil, Târîhü Nasâräül-'Trâk, s. 130.

140 BOA, KK.d nr. 3813, s. 23, 26, 27, 28, 29, 30, 31, 34.

$141 \mathrm{Bu}$ isimle anılan iki köy mevcuttu: Birinin ahalisi Hristiyan, diğerinin ise Müslümandı. Köylerin her ikisi de Hz. Nebî Yunus Vakfi köylerindendi. Yâsîn el-Ömerî, Meniyyetü'ludebâ', s. 133 .

142 2'si ednadır.

143 Tamamı ednadir.

144 Tamamı ednadır.

145 Tamamı ednadır.

146 Murat Alanoğlu, "86 Numaralı Mühimme Defterinin Özeti Transkripsiyonu ve Değerlendirilmesi”, (Yüksek Lisans Tezi), Atatürk Üniversitesi Sosyal Bilimler Enstitüsü, 2010, s. 208-209.

147 BOA, MAD, 2742, s. 67 (10 Receb 1076/16 Ocak 1666). 
1084/1673-74'te, Musul ve civar köyler tauna ve çekirge istilasına maruz kalmıştı. ${ }^{148}$ Son çekirge istilası üzerinden birkaç sene geçmişti ki Necdî çekirgesinin yine Musul kırsalındaki yağmur kıtlı̆̆ı çeken tarlaları istila etmesiyle Musul'da açlık ve pahalılığı tetiklemişti. Bunun üzerine birçok insan iaşesini temin için göçmüştü. ${ }^{149} 1087 / 1676-77$ 'deki kuraklık da gıda fiyatlarının yükselmesine ve açlığa yol açmıştı. ${ }^{150}$ 1099/1687-88'de de çekirgeler yine köylünün ekinlerine zarar vermiş̧i. 1100/1688-89'daki çekirge istilası, kuraklık ve pahalılık reayanın perakende olmasına neden olmuş ve hatta ekim yapılmasına rağmen bir habbe dahi alınamamıştı. ${ }^{151}$ Bunlara ilaveten bazı belgeler, Musul kırsalına ilişkin genel bir fikir yürütülmesini sağlayacak niteliktedir. Mesela Bârgîreli Sagîr Köyü, Körmezîn?

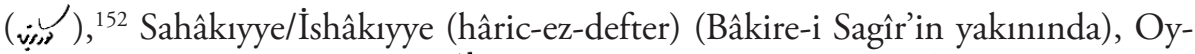

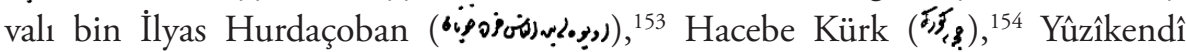
Mezrası'nın ${ }^{155}$ yakınında bulunan Şevrek, Arpa Depe ${ }^{156}$ ve Şeyh Nûr ${ }^{157}$ gibi köy ve mezraların uzun zaman boş kaldığı ve harap olduğu saptanmıştır. Ba'şîka'nın yakınlarında olan Âhîcûk Mezrası da senede 2.000 akçe Musul Hazinesi'ne verilmek üzere tasarruf edilmesi için tevcih edilmiş, ancak mutasarrıfının terk-i diyar etmesiyle mezra boş kalmış ve harap olmuştu. ${ }^{158}$ Belîn Harâsı ( aynı sebepten viran olmuştu. ${ }^{159}$

\section{24 Haziran 1694 Tarihli Hükme Göre ${ }^{160}$ Musul'daki Cizyegüzârlar}

1691-92 tahririnden yaklaşık iki yıl sonra cizyegüzârların şikâyetleri üzerine yazılan 1694 tarihli hüküm, farklı değerler sunmaktadır. Valiler ve tahsildarlar, Musul'un merkezi ve köylerindeki cizyegüzârların yıllık ödedikleri 55.975 akçe

148 el-'Udûl, "el-Kevâris”, s. 6.

149 el-'Udûl, "el-Kevâris", s. 10.

150 el-'Udûl, "el-Kevâris”, s. 12.

151 Yâsîn el-Ömerî, Meniyyetüll-udebâ', s. 175-176.

152 BOA, MAD nr. 2935, 25 Aralık 1687 (19 Safer 1099), s. 66.

153 BOA, MAD nr. 2935, 26 Aralık 1687 (20 Safer 1099), s. 67.

154 BOA, MAD nr. 2935, 27 Mart 1688 (24 Cemâziye'l-evvel 1099), s. 198.

155 BOA, MAD nr. 2935, 9 Nisan 1688 (7 Cemâziye’l-âhir 1099), s. 218.

156 BOA, MAD nr. 2935, 8 Temmuz 1688 (9 Ramazân 1099), s. 352.

157 BOA, MAD nr. 2935, 21 Temmuz 1688 (22 N 1099), s. 366.

158 BOA, MAD nr. 2935, 28 Ocak 1688 (24 Rebîü̈l-evvel 1099), s. 112-113.

159 BOA, MAD nr. 2935, 28 Ocak 1688 (24 Rebî‘ül-evvel 1099), s. 113.

160 BOA, C.ML nr. 342/14069 24 Haziran 1694 (gurre-i Zi'l-ka'de 1105). 
ispençeden fazlasını toplamaktaydı. Ayrıca reayadan bazılarının ölümü, bazılarının perakende olmaları durumlarını daha da ağırlaştırmıştı. Defterhanede yıllık 55.975 akçe maktuları kayıtlıydı. Zimmilerin tahrir edilip maktu olan ispençeden her nefere isabet eden miktarın tahsili için emir istenmişti. Şehirde 957 nefer ve 23.925 akçe maktusu, Tell Üsküf'ün 312 nefer ve 7.800 akçe maktusu, Alkuş’un 314 nefer ve 7.850 akçe maktusu, Bartalla’nın 156 nefer ve 4.100 akçe maktusu olmak üzere toplam olarak 2.307 nefer ve yıllık 55.975 akçe maktuları kayıtlıydı. 1691-92 yılı defteriyle 1694 tarihli hüküm öncelikle nefer sayısı bakımından farklıdır. Ayrıca defterdeki köylerin çoğu hükümde verilmemiştir. İki kaynaktaki nefer sayılarının farklılığı ya emred ve mürâhıkların cizye ünitesine eklenmesinden ya yerini yurdunu terk edenlerin tekrar Musul'a dönmesinden veyahut tahrir esnasında gizlenen veya himaye edilenlerin daha sonra kaydedilmesinden kaynaklanıyordu. Öyle görünüyor ki diğer köylerde sakin cizyegüzârlar 1694'te Tell Üsküf, Alkuş ve Bartalla köylerinin ismi altında kaydedilmiş.

\section{Kaza Merkezindeki Cizyegüzârların Meslekleri}

İncelenen cizye defterine ilaveten, meslekleri kapsayan aynı döneme ait farklı bir kaynağa rastlanmamıştır. Defterler de çoğu zaman meslekleri tam olarak içermemektedir (XVI. yüzyıl için bkz. Ek-1). Musul'da meslekleri bilinenlerin oranı \% 96,79'dur. Bu oran, değerlendirmeler için yeterli niceliktedir. Şehirdeki 841 neferden -çıraklarla (şâkirdler) birlikte- mesleği kayıtlı olan 814 cizyegüzârın \% 42,14’ü dokumacılık ve dokumacılığın yan kollarında çalışmaktaydı. Bu koldaki zanaatkârların çoğu Dergâh-1 Nestûrîdde (\% 30,32'si) ve Dergâh-1 Ya'kûb'da (\% 30,30'u) toplanmıştı (bkz.Tablo-3). Mukayese yapmak gerekirse, Hama'nın merkezindeki cizyegüzârların \% 27,27'si, ${ }^{161}$ Humus'takilerin ise \% 35,94' ${ }^{162}$ dokuma ve dokumacilığın yan kollarına kayıtlıd ${ }^{163} .{ }^{163}$ Ancak Hama’da ve Humus'taki cizyegüzârlar arasında dokumacilı̆ga fazla rağbet olmasına rağmen, boyacılığa rastlanmamıştır. Bunun sebebi ya boyacılı̆̆ın Müslümanların tekelinde olmasından ya da bu şehirlerin başka şehrin boya sanayisine bağımlı olmasındandı.

$161 \mathrm{Bu}$ oranı abacı, bûşîci, çulha ve çırakları, çûlhîbûşî, darakcı, terzi ve çıraklarla yüncüler oluşturmaktaydı. BOA, MAD nr. 3649, s. 4-9, 29-34 (1102/1690-91).

$162 \mathrm{Bu}$ oran bezzaz, çulha ve çırakları ile terzi ve çıraklarından oluşuyordu. BOA, MAD, nr. 3649, s. 9-12, 34-36 (1102/1690-91).

163 BOA, MAD nr. 3649, s. 3-36 (1102/1690-91). 
37 bennânın 16'sı Dergâh-1 Nestûrîde 13'ünün ise Dergâh-1 Ya'kûb'da ve bennâ çıraklarının da yalnız bu mahallelerde kaydedilmiş olmaları, bu yerlerin nüfus yoğunluğundan (bkz. Tablo-3) ve para dolaşımının merkezleri olduğundandı. Çünkü yapı işlerinin gelişimi ve devamlılı̆̆ı, toplumun ihtiyacıyla birlikte, geliriyle de doğrudan alakalıydı. Bununla birlikte Musul'da Dergâh-1 Nestûrîde (bkz. Tablo-3), Hama ve Humus'ta ise Nasâra mahallelerinde olduğu gibi bennâların/ mimarların, çulhalarla ${ }^{164}$ kuyumcuların yoğun olduğu mahallelerde toplanmaları, kalabalık semtleri ve para trafiğini takip etmelerindendi. Nitekim nitelikli meslekler (kuyumcular ve kumaş tacirleri gibi), şehir merkezlerinin yakınında faaliyet gösteriyordu. ${ }^{165}$ Bu yüzden Dergâh-1 Nestûrî, ya şehrin merkezî bir yerindeydi veya oraya yakın bir konumdayd.

Şam şehrinde toplam 2.424 cizyegüzârın 143 'ü (\% 5,90'1), ${ }^{166}$ Musul'da 1.576 neferin 37'si (\% 2,35'i) (bkz. Tablo-3), Hama'da 275 neferin 13'ü (\% 4,73'ü) ve Humus'ta ise 217 cizyegüzârın 7'si (\% 3,23'ü) mimard. ${ }^{167}$ Defterde bennâ kavramı mevcutken, mimarbaşı kavramı geçmiyor (bkz. Tablo-3); ancak bir hükümde Musullu zimmilerden Mimarbaşı İlyas veled-i Abdülahad ve Demirci Murat veled-i Hadar'dan bahsedilmişti. Fakat defterde bu isimlere rastlanmamıştır. Bunların Van'da bulundukları ve Musul valisi tarafından görevlendirildikleri anlaşılıyor. Bu yüzden de cizyeden muaf olmaları muhtemeldi. Musul'daki esnaf taifesi, yaptıkları işten dolayı yiyecek, içecek, giyecek ve diğer asli ihtiyaçlara ilişkin tüm haklarını validen almış ve buna ilişkin mahkemede bir hüccet hazırlanmıştı. ${ }^{168}$ Sayısal olarak Musul'daki rencberler ${ }^{169}$ ilk sıradaydı (bkz. Tablo-3).

164 Çulha/culha, el tezgâhında bez dokuyan kimsedir. İlhan Ayverdi, Asırlar Boyu Târihî Seyri İcinde Misalli Büyük Türkçe Sözlük,(İstanbul: Kubbealtı Lugatı, 2011), I, s. 614.

165 Andre Raymond, Osmanlı Döneminde Arap Kentleri, çev. Ali Berktay (İstanbul: Alfa/Tarih, 2018), s. 223.

166 Samıkıran, "Nefs-i Şam”, s. 222-223, 237.

167 BOA, MAD nr. 3649, s. 3-36 (1102/1690-91).

168 BOA, AE.SAMD.II, 90/8944 14 Aralık 1708 (gurre-i Şevvâl 1120).

169 Rencber, sanat ehli ve ehl-i hırfet anlamlarına gelirken rencberlik etmekse alıp-satmak ve ticaret yapmak anlamındadır. Tulum, 17. Yüzyıl Türkçesi, s. 1494. "Âhar vilâyetlerden gelen rencber ü tüccâr" ibaresi de bunu desteklemektedir. 12 Numaralı Mühimme Defteri (978-979/1570-1571): Özet, Transkripsiyon ve Indeks, (Ankara: Başbakanlık Devlet Arşivleri Genel Müdürlüğü Osmanlı Arşivi Daire Başkanlığı Yayınları, 1996), I, s. 299. Rencberlerin, cizyegüzârların Musul Şehri’nde en yoğun olduğu ve üretim ve pazarlamanın merkezi statüsünde olduğu düşünülen Dergâh-1 Nestûrîde sayıca daha fazla olmaları ve ayrıca dokumacılar ve dokumacılığın yan kollarındaki esnafın toplandığı mahallelerde yoğunlaşmalarına bakılırsa, bu grup, sermaye ve zanaat sahibi ve/veya hamal statüsündekileri 
275 neferin bulunduğu Hama’nın merkezi ile 217 nefer cizyegüzârlı Humus’un merkezinde de rencberler çoğunluktaydı. Hama'da rencberlerden sonra kuyumcular (47 cizyegüzâr) ve çulhalar (43) gelirken; Humus'ta da rencberleri çulhalar (64), ekmekçiler (16) ve kuyumcular (13) izlemekteydi. ${ }^{170}$

Ham ve yarı işlenmiş maddeyle ilgilenen zanaatkârlarla mamul mal üretenler debbağlarla pabuççular gibi aynı mahalledeydi (bkz. Tablo-3). Pabuç üreten 5 cizyegüzârın 2'si Kal'a-1 Ya'kûb'da sakinken, diğer 2'si "çok usta pabuççuların ve çizmecilerin" ${ }^{171}$ bulunduğu Diyarbakır'dan, 1'i ise Mardin'dendi. Diyarbakırlılardan biri Köprüyapan Mahallesi'nde pabuççu iken, diğeri Kubad Beğ Mahallesi'nde pabuççu çırağıydı. Diyarbakır cizye defterinde bu isimler kayıtlı değildir. Köprüyapan'da sadece bir çizmeciye rastlanması ${ }^{172}$ ve pabuççu çırağının mahalleden ayrılışıyla Kubad Beğde sadece bir pabuççunun kalması, ${ }^{173}$ her ikisinin de Musul mazısını temin etmek için şehirden ayrıldığı ihtimalini kuvvetlendiriyor. Çünkü deri tabaklamada ve boyacılıkta kullanılan mazı Halep’e göre Musul'da daha ucuzdu. ${ }^{174}$ Ayrıca XVIII. yüzyılın son çeyreğinde bir İngiliz seyyahın bahsettiği Musul'daki "çok nefis sahtiyan” üretimi ${ }^{175}$ de cazipti.

Bitlis perakendelerinin tamamı ve Van perakendelerinin ise 2/3'si kürkçülükle uğraşmaktaydı (bkz. Tablo-3). Bunların Musul'da bulunma sebebi muhtemelen kürk ticaretiydi. Çünkü Tavernier'in kervanındaki samur kürk yüklerinden,

tanımlamaktaydı. Rencberlerin para karşılığında emek, zanaat ve sermaye (hamal ve bazirgan gibi) harcayan bir esnaf grubu olduğuna dair Üzeyir beyine gönderilen hüküm için bkz. BOA, A.DVNS.MHM.d nr. 23, 125/254 10 Kasım 1573 (15 Receb 981); Bağdat beylerbeyine yazılan hüküm için bkz. BOA, A.DVNS.MHM.d nr. 36, 47/142 1 Şubat 1579 (4 Zi'l-hicce 986); Eflak beyine yazılan hüküm için bkz. BOA, A.DVNS.MHM.d nr. 46, 124/245 4 Ekim 1581 (6 Ramazân 989); koyun toplayıp satan rencber taifesine dair Şam beylerbeyine yazılan hüküm için bkz. BOA, A.DVNS.MHM.d nr. 46, 369/856 7 Mart 1582 (11 Safer 990); Mısır beylerbeyine yazılan hüküm için bkz. BOA, A.DVNS. MHM.d nr. 60, 165/363 22-31 Ocak 1586 (Evầil-i Safer 994); BOA, MAD nr. 2935, 15 Ağustos 1688 (17 Şevvâl 1099), s. 396. Ayrıca arabalarıyla rencberlik eden arabacılar esnafı için Edirne kadısına gönderilen hüküm için bkz. BOA, A.DVNS.MHM.d 74, 31/114, 14 Temmuz 1596 (18 Zi’l-ka'ade 1004 ).

170 BOA, MAD nr. 3649, s. 3-36 (1102/1690-91).

171 Der Andreasyan, Simeon'un Seyahatnâmesi, s. 118.

172 BOA, MAD nr. 3639, s. 25 (1104/1692-93).

173 BOA, MAD nr. 3639, s. 29 (1104/1692-93).

174 M. Sait Türkhan, '18. Yüzyılda Doğu Akdenizde Ticaret ve Haleb” (Doktora tezi, İstanbul Üniversitesi, 2014), s. 53, 54.

175 ed-Dîveci, Ticâretül-Mevsıl, s. 29. 
Musul'un samur kürk ticaretinin güzergâhında olduğu anlaşıyor. ${ }^{176}$ Söz konusu bölgelerde kürk ticareti yaygındı. Erzurum'da "çok büyük" bir sansar (zerdevâ) ticareti yapılmaktaydı. ${ }^{177}$ Dergâh-1 Nestûrîde ve Kal'a-1 Ya'kûb'da 4’er, Dergâh-1 Ya'kûb’da 3 ve Kal'a-1 Nestûrîde 1 semerci mukimdi. Ulaştırma hizmetlerinde hayvanların rolü dikkate alınırsa palancılar en fazla insan ve ticari mal akışının yoğun olduğu semtlerde konuşlanmış olmalıydı.

176 Tavernier, Tavernier Seyahatnamesi, s. 205-206.

177 Tournefort, Tournefort Seyahatnamesi, s. 130. 
OĞUZHAN SAMIKIRAN

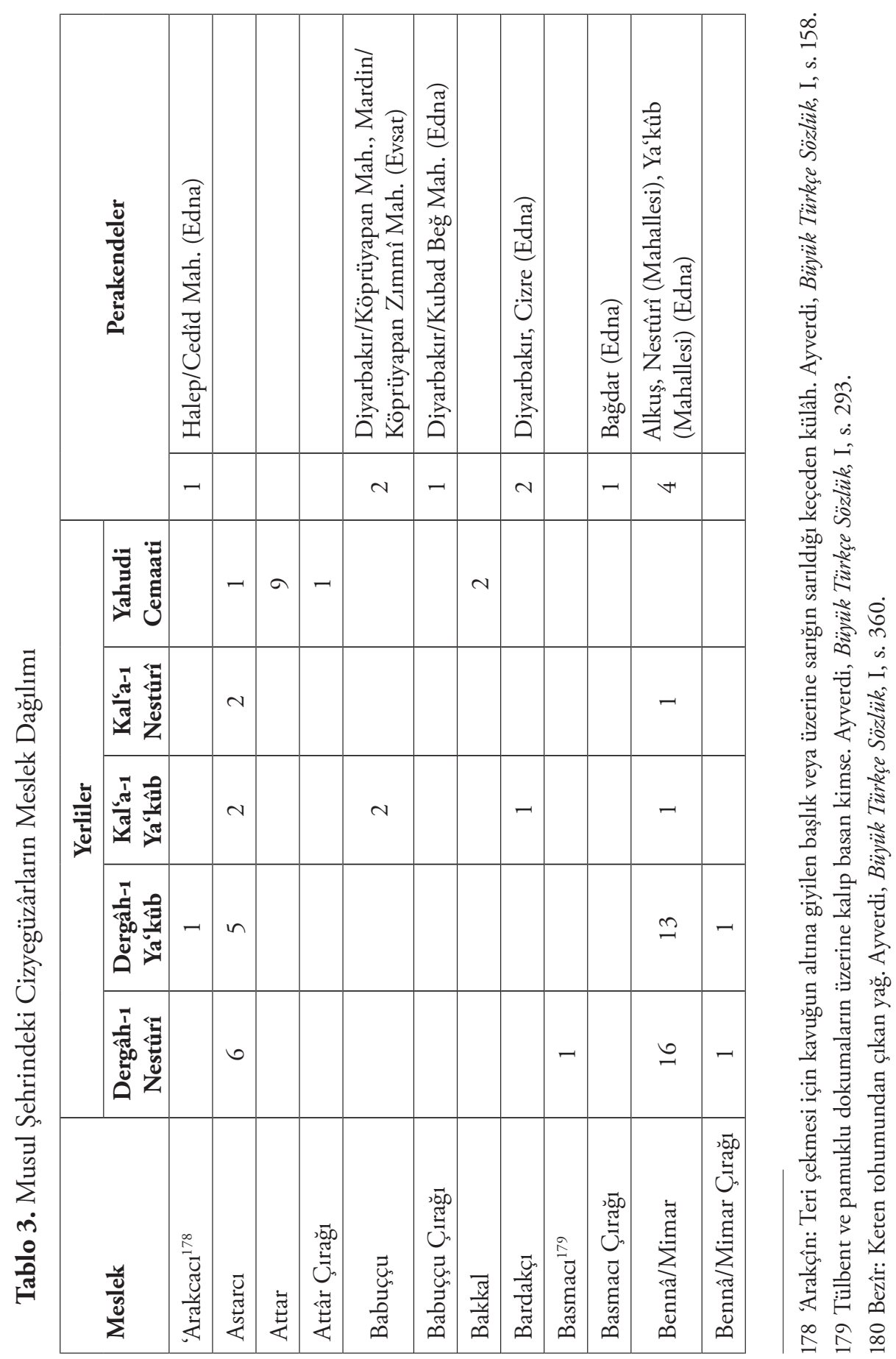


MUSUL KAZASI'NIN CİZYEGÜZÂRLARI VE BÖLGESEL İLİŞKİLERİ

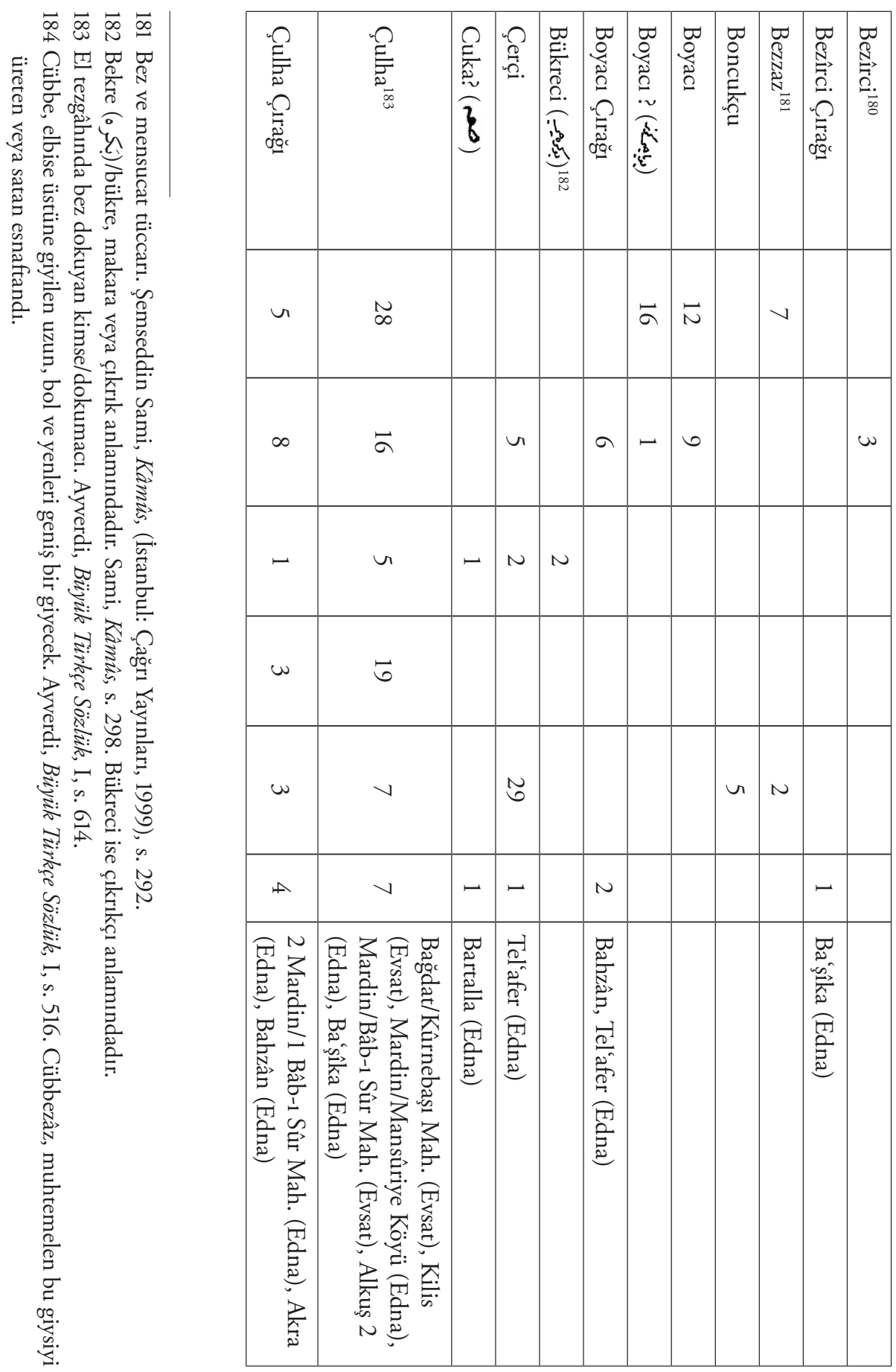


OĞUZHAN SAMIKIRAN

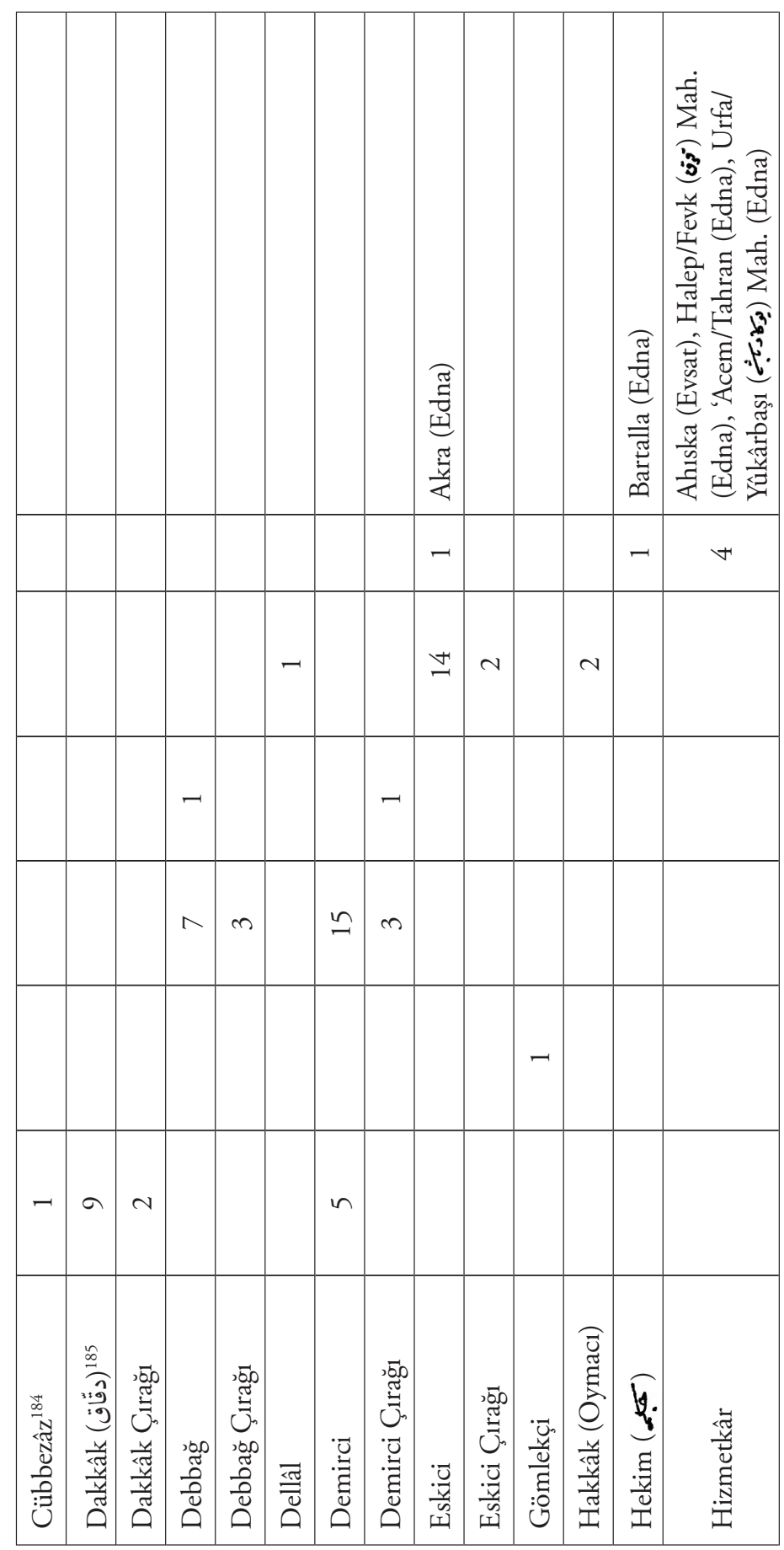

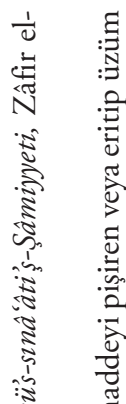

इ छ

$2 \pi$

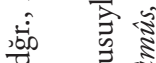

$>\quad 5$

获

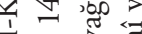

$\dot{\omega}$ is

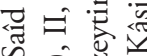

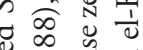

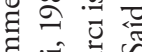

氖

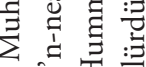

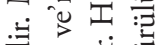

可:

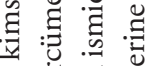

चี

ते

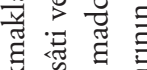

然箩

크 크

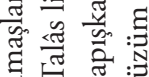

灵: 零:

㐘 :

㱐 喜

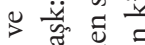

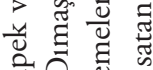

$\because \ominus \stackrel{5}{5}$

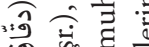

नु 包

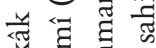

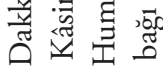

$\infty$ 
MUSUL KAZASI’NIN CİZYEGÜZÂRLARI VE BÖLGESEL İLİŞKİLERİ

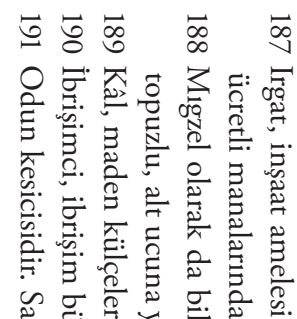

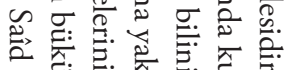

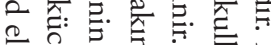

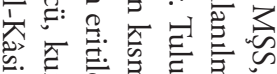

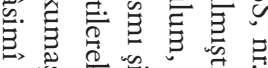

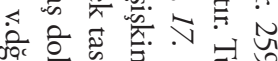

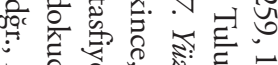

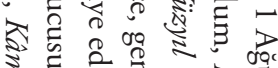

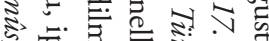

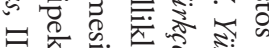

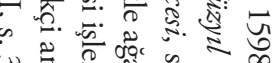

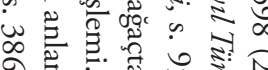

的记

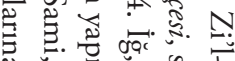

o $\frac{1}{5}$ 它

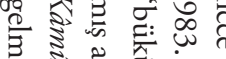

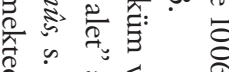

하워

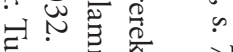

夏产证

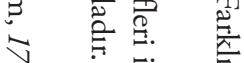

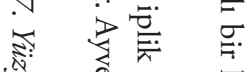

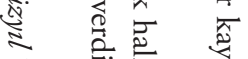

고 웅

ㄱำ

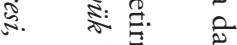

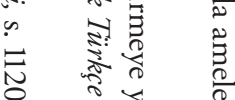

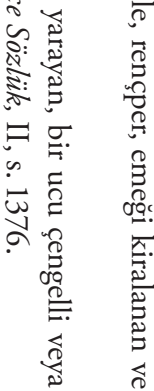
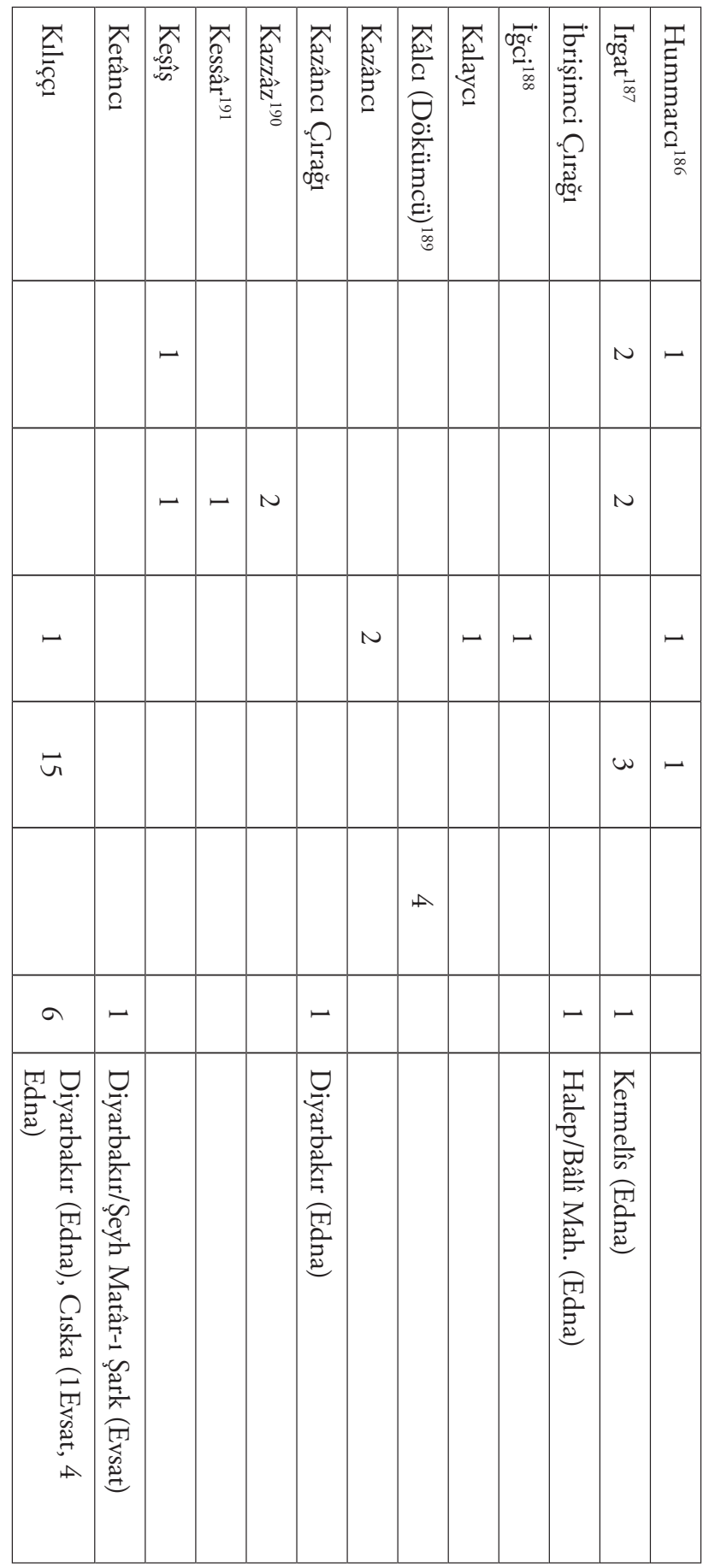
OĞUZHAN SAMIKIRAN

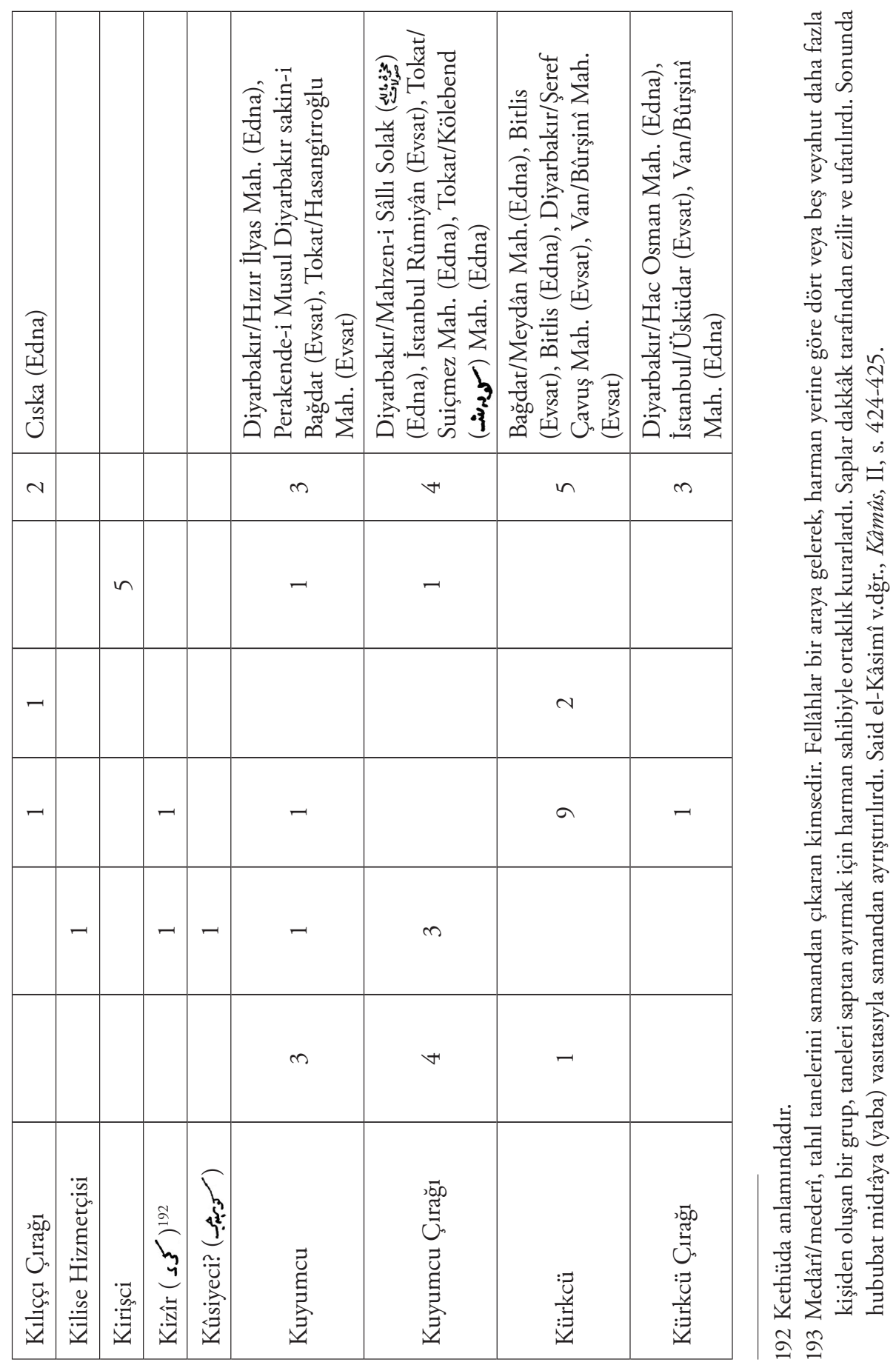


MUSUL KAZASI'NIN CİZYEGÜZÂRLARI VE BÖLGESEL İLİŞKİLERİ

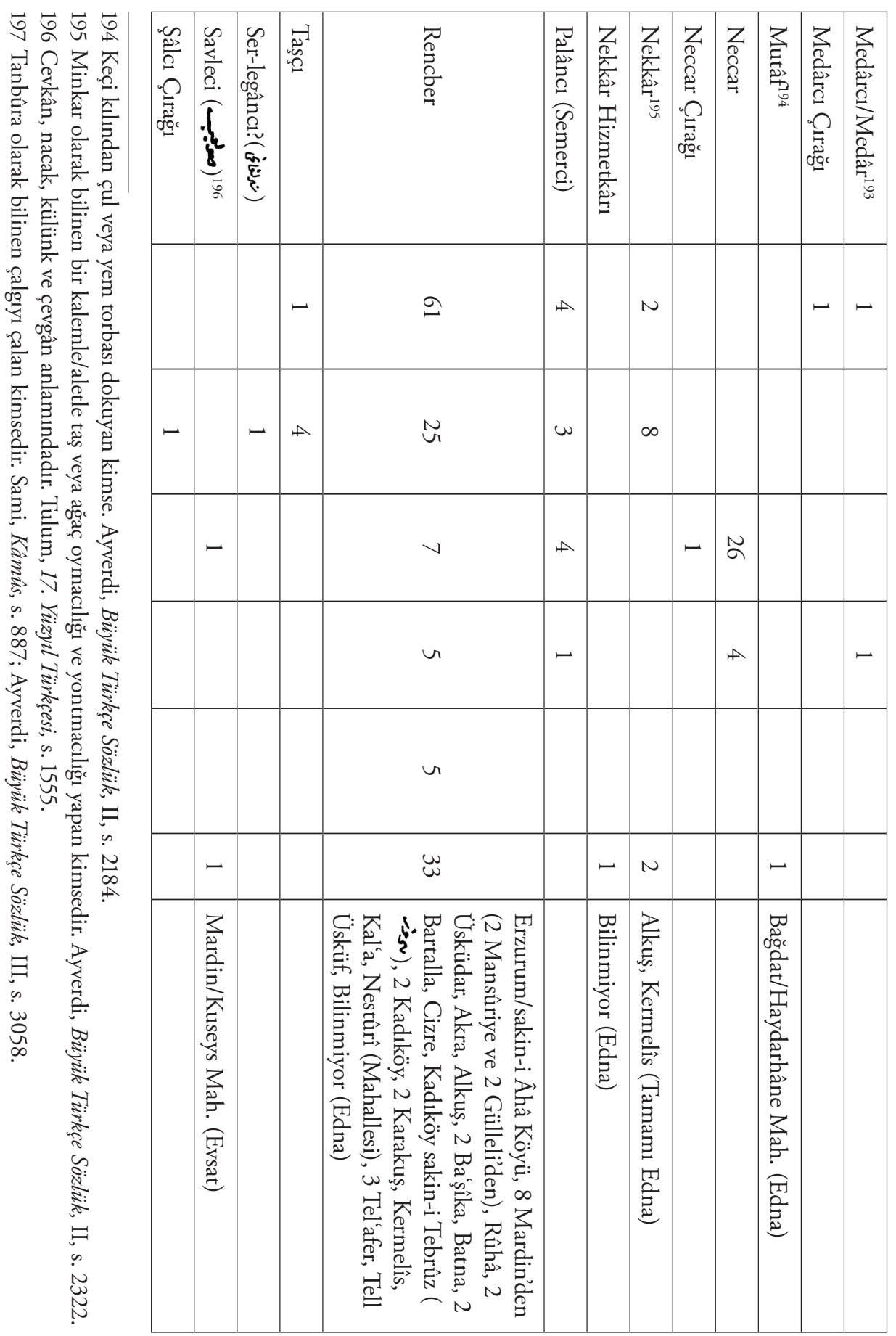


OĞUZHAN SAMIKIRAN

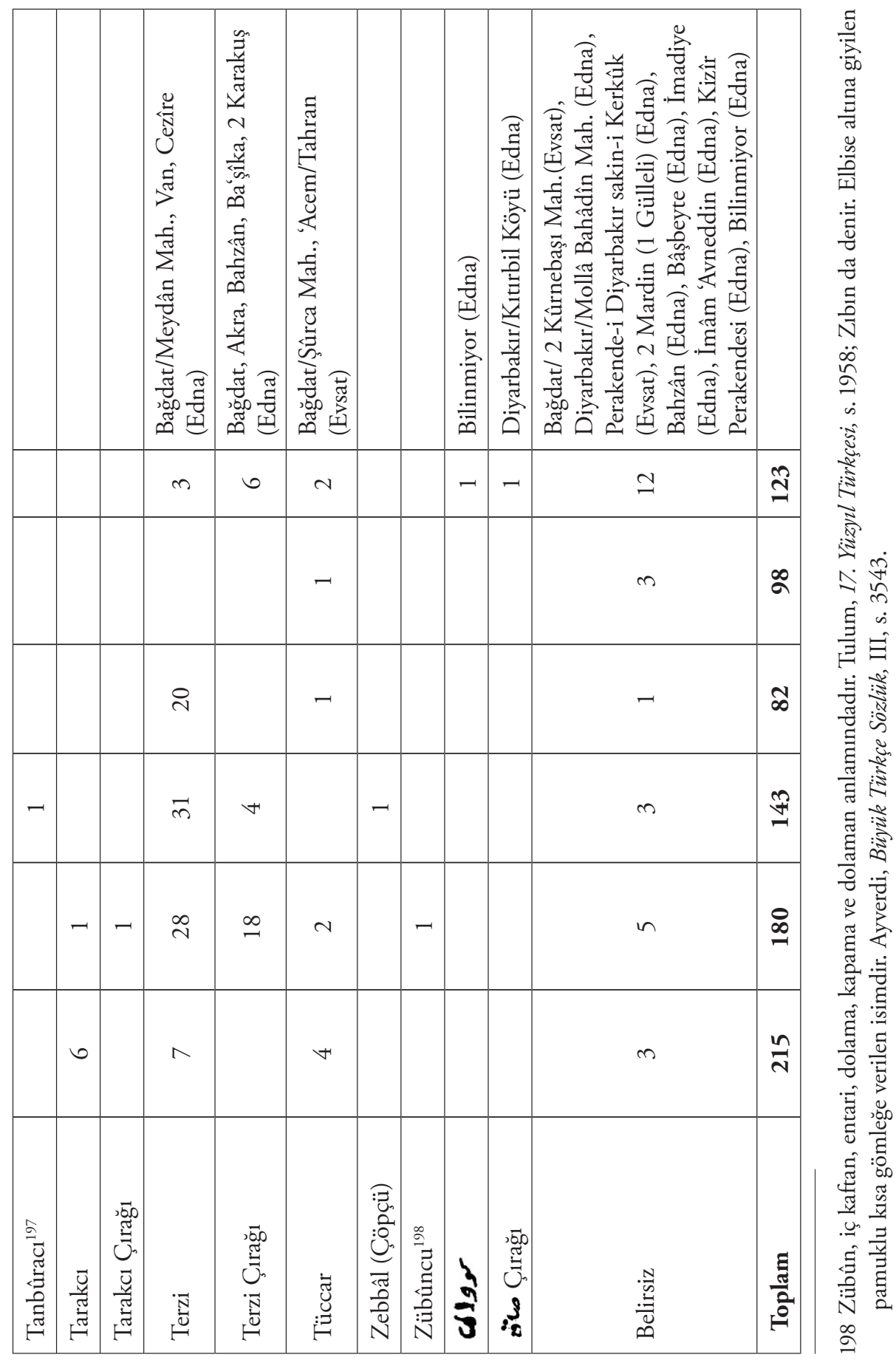


Musul'un iki nehir arasında bulunması ve nehir taşımacılığının yaygınlığı sebebiyle aynı mahalledeki esnaf arasında işbölümü kaçınılmazdı. Keleklerin üretiminde ve işletilmesinde keçi postuna, ahşaba, keçeye ve insan gücüne ihtiyaç duyuluyordu. ${ }^{199}$ Yani keçi yetiştiricisi/tüccarı, postları dikmek için terzi, keresteci, marangoz, keçeci, amele gibi grupların istihdamını gerektiriyordu. Debbağ, terzi, marangoz ve demirci gibi esnafın Kal'a-ı Ya 'kûb'da yoğunlaşması (bkz.Tablo-3), nehir ulaşım vasıtalarının üretiminde mahallenin rolüne işarettir. Nitekim Musul, Dicle'deki kelek taşımacılığının başlangıç noktası olmakla birlikte aynı zamanda keleklerin merkezi olarak bilinen iki şehirden (diğeri Diyarbakır) biriydi. ${ }^{200}$

Kaza merkezindeki mesleklere ilişkin veriler yeterliyken, bu, kırsal kesim için geçerli değildir. Buna rağmen "Tellkeyf perakendeleri” başlığ 1 altında 2 rencbere, ${ }^{201}$ Karakuş'taysa 1 boyacı, ${ }^{202} 2$ demirci $^{203}$ ve 1 rencbere ${ }^{204}$ rastlandı. Perakendeler, mesleklerine göre yedi grupta toplanmıştı: a-Rencberlik b-Dokumacilık ve dokumacılığın yan kollarında çalışanlar c-Metal işleriyle uğraşanlar d-Deri mamulleriyle ilgilenenler e-Yapı işleriyle uğraşanlar $\mathrm{f}-$ Tüccar g-Diğerleri. 123 yabancının \% 26,82'si rencber, \% 8,94'ü çulha, \% 7,32'si terzi, \% 6,50'si kılıççı, \% 6,50'si kürkçü ve \% 5,69'u kuyumcuydu (bkz. Tablo-3). Şehirdeki toplam 21 kuyumcunun $1 / 3$ 'inin yabancilardan oluşması, İsfahan'a doğru giden ve Taverneir' in de bulunduğu kervanda kuyumcuya rastlanılması, ${ }^{205}$ gümüşün - muhtemelen altının da - İran'da pahalı olması ve İranlıların gümüş merakındandı ${ }^{206}$ Mardin, \%

199 Tavernier, Tavernier Seyahatnamesi, s. 208.

200 Cengiz Orhonlu-Turgut Işıksal, "Osmanlı Devrinde Nehir Nakliyatı Hakkında Araştırmalar Dicle ve Fırat Nehirlerinde Nakliyat”, Tarih Dergisi, XII/17-18 (1963), s. 86, 87; Kelekler hakkında ayrıntılı bilgi için bkz. Nejat Göyünç, "Dicle ve Fırat Nehirlerinde Nakliyat”, Belleten, LXV/243 (2001), s. 655-665; 'Âmir Bellû İsmail, “el-Eklâkü fi'l-Mevsıl min hilâli müdevvenâti'r-rahhâleti'l-ecânibi”, Mecelletü Dirâsâti Mevsıliyyetü, el-'adedü'ssâdisü'l-'işrûne, (2009), s. 129-143.

201 BOA, KK.d nr. 3813, s. 23.

202 BOA, KK.d nr. 3813, s. 26.

203 BOA, KK.d nr. 3813, s. 28.

204 BOA, KK.d nr. 3813, s. 29.

205 Tavernier, Tavernier Seyahatnamesi, s. 283.

206 Tavernier, Tavernier Seyahatnamesi, s. 298. Gizlice düşük fiyatla gümüş alıp Acem vilayetine ziyade fiyatla satıldığına, doğuya ve diğer vilayetlere gümüş, altın, kuruş, bakır ve kurşunun kaçırıldığına dair Halep defterdarına yazılan hükümler için bkz. BOA, A.DVNS. MHM.d nr. 27, 164/377 4 Aralık 1575 (12 Ramazân 983); BOA, A.DVNS.MHM.d nr. 28, 11/22 26 Ağustos 1576 (gurre-i Cemâziye'l-âhir 984); BOA, A.DVNS.MHM.d, nr. 39, 128/303 26 Ocak 1580 (8 Zi'l-hicce 987). 
24,24 oranla Musul'a en fazla rencber gönderen şehirdi. Toplam 136 rencber arasında yabancıların oranı \% 24,26'dır. Farklı kentlerden Musul'a gelen 6 çulhanın 4’ü Mardinliydi (bkz.Tablo-3). Mardin’in Bâbü's-Sûr Mahallesi'nde Müslümanların da dokuma dükkanları vardı. ${ }^{207}$ Mansûriye'de de bir zimminin terekesinde çulha aletine rastlanmıştır. ${ }^{208}$ Perakendelerden sadece bir kişi ketenle uğraşıyordu. Musul'a göçen bu ketenci, Diyarbakır'da Şeyh Matâr-1 Şark Mahallesi'ndeki son ketenciydi; çünkü bu mahallede cizye mükellefi olan başka bir ketenci yoktu. ${ }^{209}$

Kılıççılardan 8'i Diyarbakır ve Cıska'dan Musul'a gitmişti (bkz. Tablo-3). 1104/1692-93 ve 1105/1693-94 yıllarını kapsayan makalede kılıççılara rastlanmaması ilginçtir. ${ }^{210}$ Oysaki Diyarbakır'da cizyegüzâr kılıççı esnafının varlığını cizye tezkeresi onaylıyor. ${ }^{211}$ Bununla birlikte Cıska'nın Ermeni kılıççı çıraklarına Humus'ta da rastlanıyordu. ${ }^{212}$ Musul'da \% 3,62 oranında bir kılıççı esnafinın kayıtlı olması ve buna karşılık Hama merkezinde \% 0,73, Humus'ta ise \% 0,46 oranında (bkz. Tablo-5) bir niceliğe sahip olan kılıççılara Şam’daki cizyegüzârlar arasında rastlanmaması, Musul'un hudut şehri olmasından kaynaklanıyordu.

Mardin ve Diyarbakır'dan Musul'a gidenlerden çoğunun ismine 3639 numaralı defterde rastlanmaması, Musul'da kaydedildikleri anlamına geliyor. Ancak Musul cizye defterinde "Diyarbakır Şeref Çavuş Mahallesi Onan veled-i Derviş Kürkçü” şeklindeki kaydın benzeri ${ }^{213}$ Diyarbakır cizye defterinde de mevcuttu. ${ }^{214} \mathrm{Bu}$ kişi, o mahallede kürkçülükle iştigal eden tek kişiydi. Bu, kişinin hem Diyarbakır'da hem de Musul'da kaydedildiğini gösteriyor.

43 yabancıdan sadece meslekleri kayıtlı olanlar Tablo-4'e aktarılmıştır. Bunlar, Tablo-3’teki perakendelerin dışında tutulmuş ve ayrı olarak değerlendirilmiştir.

207 MŞS, nr. 259, 27 Mayıs 1599 (2 Zi'l-kaade 1007), s. 70; MŞS, nr. 203, (21 Nisan 1719

(gurre-i Cemâziye'l-âhir 1131), s. 67.

208 MŞS, nr. 248, 25 Kasım 1689 (12 Safer 1101), s. 40.

209 Bkz. BOA, MAD nr. 3639, (1104/1692-93), s. 6-7.

210 Mehmet Salih Erpolat, "Cizye Defterlerinin Sosyal ve İktisadî Tarih Araştırmaları Açısından Önemi: Diyarbakır Örneği”, Akademik Araştırma ve Dayanı̧ıma Derneği Sosyal Bilimler Araştırma Dergisi (SBArD)", 4 (2015), s. 199-201.

211 Diyarbakır-Amid cizyesine tabi edna statüsündeki "Muslu veled-i Birek Kılıççı" Diyarbakır’ın cizyegüzârları arasında bulunmamaktadır. BOA, D.CMH, 236/120 16 Mayis 1692 (29 Şa'bân 1103).

212 BOA, MAD nr. 3649, (1102/1690-91), s. 36.

213 BOA, KK.d nr. 3813, s. 36.

214 BOA, MAD nr. 3639, (1104/1692-93), s. 35. 
Tablo 4. Yerliler Arasına Perakende Olarak Kaydedilmiş Cizyegüzârlar

\begin{tabular}{|l|c|l|l|l|}
\hline Meslek & Adet & $\begin{array}{l}\text { Geldiği Yer } \\
\text { (Şehir/Mahalle) }\end{array}$ & $\begin{array}{l}\text { İktisadi } \\
\text { Vaziyeti }\end{array}$ & $\begin{array}{l}\text { Kaydedildiği } \\
\text { Mahalle/Köy }\end{array}$ \\
\hline Rencber & 1 & Bilinmiyor & Edna & Dergâh-1 Nestûrî \\
\hline Çerçi & 3 & Mardin/Hatun & Edna & Yahudi \\
\hline Çerçi & 1 & Mardin/Bâb-1 Cedîd & Edna & Yahudi \\
\hline Çerçi & 1 & İmadiye & Edna & Yahudi \\
\hline Çerçi & 1 & Diyarbakır & Edna & Yahudi \\
\hline Kâlcı & 1 & Bağdat & Evsat & Yahudi \\
\hline Rencber & 1 & Halep & Edna & Yahudi \\
\hline Tüccar & 1 & Halep & Evsat & Yahudi \\
\hline Demirci & 1 & Bilinmiyor & Edna & Karakuş \\
\hline Demirci & 1 & Mardin & Bilinmiyor & Karakuş \\
\hline Rencber & 1 & Bilinmiyor & Bilinmiyor & Kermelîs \\
\hline
\end{tabular}

İktisadi açıdan zayıf olan Musul'daki Yahudiler, şehirdeki para trafiğinden uzak bir muhitte sakindiler. ${ }^{215}$ Yahudi Mahallesi'ndeki çerçiler (bkz. Tablo-4) muhtemelen Yahudiydi. Çünkü çerçicilik, Yahudiler arasında yaygındı. Mesela Şam'daki çerçilerin \% 82,54'ü Yahudiydi. ${ }^{216}$ Cizyegüzârlara ait mülklerin bulunduğu Bâbül-Cedîd'de bir Yahudi mabedinin varl $\breve{g ̆}_{1}{ }^{217}$ Yahudilerin bu mahallede bir cemaate sahip olduğunu gösteriyor. Yahudi Mahallesi'ni tercihlerinin sebebi ya din kaygısıydı ya mesleklerinden dolayı iktisadi bir kaygıydı veyahut her ikisiydi. Bu çerçiler birbirlerine aşinaydı ve bu yüzden grup halinde dolaşmaktaydılar. Nitekim dört çerçiden üçü Mardin'in Hatun Köyü’nden ve biri ise Bâb-1 Cedîd'dendi. Hatta Diyarbakır ve İmadiye'den gelen iki çerçinin de aynı mahallede kaydedildiğine bakılırsa tanışılardı.

Cizye defterlerde çıraklara ilişkin kayıtlar sınırlıdır. ${ }^{218}$ Deftere kaydedilecek kimsenin kisb u kâra kadir olması gerekiyor ki bu da ustanın yanında çalışırdığı

215 Raymond, Arap Kentleri, s. 111.

216 Samıkıran, "Nefs-i Şam”, s. 234, 237.

217 MŞS, nr. 259, 22 Şubat 1600 (7 Şaban 1008), s. 164.

218 Şam'daki zanaatkârlara tabi çıraklara rastlanmamıştır. bkz. Samıkıran, "Nefs-i Şam”, s. 234235, 237-239. 
ve zanaatını öğrettiği çırağa, en azından iaşesini temin edebileceği seviyede ${ }^{219}$ maddi bir olanak sunmasına bağlıydı. Bu yüzden bazı mesleklerde çıraklara rastlanmaması ya zanaattan sağlanan kazancın ancak ustanın iaşesine yettiği içindi ya da vergiden kaçmanın bir sonucuydu; çünkü aynı mahallede 16 bennâya karşılık 1 bennâ çırağının varlığı usta-çırak dağılımındaki orantısızlığı gösteriyordu (bkz. Tablo-3). Bazı çıraklar, Simeon'un "emsali yalnız İstanbul'da” olduğunu söylediği ve "çok usta" kuyumculara ${ }^{220}$ sahip Diyarbakır'dan Musul'a ustalarıyla birlikte gelmişti. Musul'da Diyarbakırlı iki kuyumcudan biri çıraktı. Muhtemelen usta Diyarbakır'da Hızır İlyas Mahallesi'nde, çırak ise Sâllı Solak Mahallesi'nde kayıtlıydı; çünkü Diyarbakır'da Sâllı Solak'ta, bu çıraktan başka bir kuyumcu yoktu. ${ }^{221}$ Yine Diyarbakır'da Hacı Osman Mahallesi'ndeki kürkçü çırağı ile Şeref Çavuş Mahallesi'ndeki kürkçü ustası birlikte Diyarbakır'dan ayrılmıştı. Çünkü Hacı Osman'da bu çıraktan başka kürkçülükle uğraşan kimseye rastlanmamıştır. ${ }^{222}$

Grafik-1 Musul Şehrindeki Cizyegüzâr Zanaatkârlara Göre Çırak Dağılımı

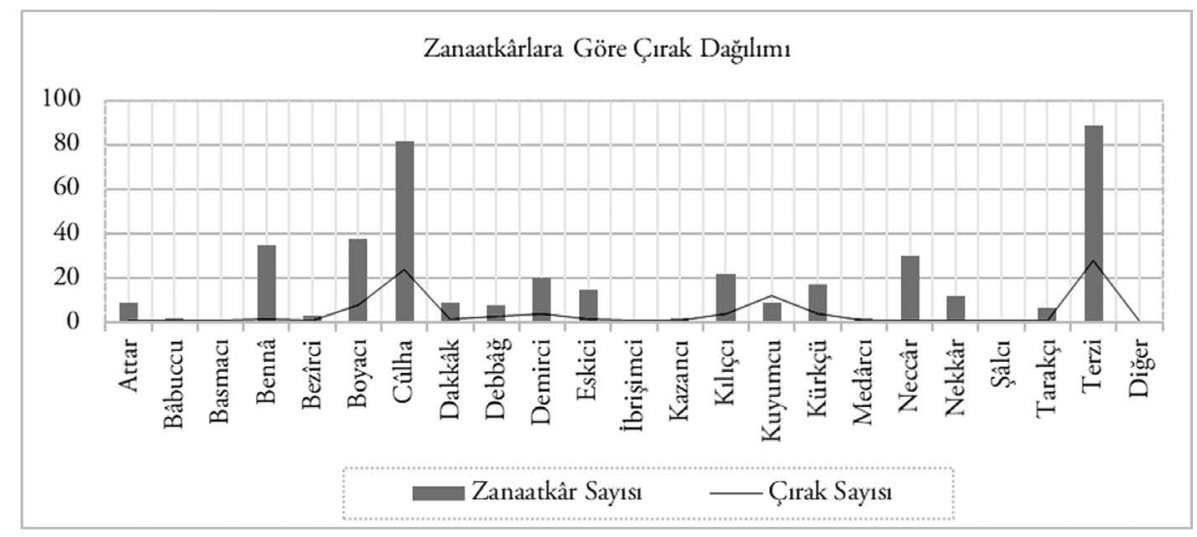

Cizye defterinde geçen "şâkird" ve "hizmetkâr" kavramları birbiri yerine kullanılmıştı. Tüm zanaatkârlar içinde çırakların oranı \% 12,90'dı. Dokumacilık en fazla çırağa sahipti (bkz. Grafik-1). Çünkü cizyegüzârlar arasında dokumacılık

219 Amid'de, emred olan Astor veled-i Hadar Beşe, Kaftâncı Âvânîs veled-i Garîb’in yanında birkaç sene çıraklık yapmış ve bu süreç zarfında ustası tarafından nafaka ve kisvesi karşılanmıştır. Sonrasında kendi rızasıyla ustasının yanından ayrılmıştır. Diyarbakır Şer iyye Sicilleri (DŞS), nr. 316, 5 Nisan 1655 (28 Cemâziye'l-evvel 1065), s. 11a.

220 Der Andreasyan, Simeon'un Seyahatnâmesi, s. 118.

221 Bkz. BOA, MAD nr. 3639, (1104/1692-93), s. 28.

222 Bkz. BOA, MAD nr. 3639, (1104/1692-93), s. 4. 
yaygındı ve muhtemelen iş yoğunluğu da fazlaydı. Bu, şehre gelecek dokumacı yabancı çırakların oranını arttırıyordu. Musul'daki yabancı çırakların nispeti \% 26,67'dir, en fazla rağbet ettikleri zanaatlar terzilik, çulhalık ve kuyumculuktu (bkz. Tablo-3). Hama şehrinde yerli ve yabancı toplam 275 -ki tamamının meslekleri kayıtlıdır- cizyegüzârın \% 9,45'i; Humus şehrindeyse 217 cizyegüzârın \% 5,53'ü çıraktı. Bu şehirlerde çulha, kuyumcu ve bennâ/mimarların çırakları ön plandaydı (bkz. Tablo-5).

Tablo 5. Hama ve Humus Şehirlerinde Cizyegüzâr Zanaatkârların Çırak Dağılımı1 ${ }^{223}$

\begin{tabular}{|c|c|c|c|c|c|c|c|}
\hline \multicolumn{4}{|c|}{ Nefs-i Hama } & \multicolumn{4}{|c|}{ Nefs-i Humus } \\
\hline \multirow{2}{*}{ Zanaat } & \multirow{2}{*}{ Zanaatkâr } & \multicolumn{2}{|c|}{ Çırak } & \multirow{2}{*}{ Zanaat } & \multirow{2}{*}{ Zanaatkâr } & \multicolumn{2}{|c|}{ Çırak } \\
\hline & & Yerli & Yabancı & & & Yerli & Yabanci \\
\hline Çulhalık & 41 & 2 & - & Çulhalık & 61 & 3 & - \\
\hline Demircilik & 11 & 5 & - & Demircilik & 3 & 2 & - \\
\hline Ekmekçilik & 3 & 3 & - & Ekmekçilik & 13 & 3 & - \\
\hline Kılıççılık & - & - & 1 & Kılıççılık & 1 & - & 1 \\
\hline Kuyumculuk & 36 & 11 & - & Kuyumculuk & 12 & 1 & - \\
\hline Mimarlık & 12 & 1 & - & Mimarlık & 7 & - & - \\
\hline Nalbendlik & 1 & 2 & - & Nalbendlik & 4 & 1 & - \\
\hline Terzilik & 6 & 1 & - & Terzilik & 6 & 1 & - \\
\hline Toplam & 110 & 25 & 1 & Toplam & 107 & 11 & 1 \\
\hline
\end{tabular}

\section{Musul'da Çiçek Hastalı̆̆ının İzleri}

Cizye defterlerine cizyegüzârların sayıları, meslekleri ve iktisadi vaziyetlerine ek olarak cizyegüzârlara isabet eden hastalığın bedenlerdeki emareleri de eşkâllerin tasviri için kaydediliyordu. Musul ve havalisinde çiçek hastalığı, vücutta kalıcı izlere ve lekelere sebep olmuştu. 1.576 cizyegüzârdan 91'inin eşkâl tasviri "yüzü çiçekli”, "yüzünde çiçek eseri var”, "yüzü çiçek burmuş”, "sol gözü hicrânlı yüzü çiçekli”, "yüzü çiçek bir gözü kördür”, "çopur ${ }^{224}$ yüzlü” ve "sol yanağı çopur”

223 BOA, MAD nr. 3649, (1102/1690-91), s. 3-36.

224 Çopur: Çiçek hastalığından dolayı yüzü delik deşik olmuş kimse için kullanılır. Halk arasında çöpür olarak da bilinmekte olup eski Türkçede çöpür, keçi kılı anlamına gelmektedir. Ayverdi, Büyük Türkçe Sözlük, I, s. 606. 
gibi ibarelerden oluşuyordu. Buna göre cizyegüzârların yaklaşık \% 6’sı çiçek hastalığına maruz kalmıştı. Çiçek izleri en fazla sırasıyla terzi (11 cizyegüzâr), rencber (10), çulha (8) boyacı (6) ve neccar (5) gibi zanaatkârların bedenlerinde görülmüştür. ${ }^{25}$ Hastalık, dokumacılıktaki işbölümü zincirini izliyordu; dokumanın hammaddesi üreticiden çulhaya ulaşır, çulhanın, marangozların imal ettiği dokuma tezgâhlarında dokumasından sonra boyanması için boyacıya teslim edilir ve boyanan bez insanların ihtiyaçlarına göre terzilerin ellerinde şekillendikten sonra tüketicilere ulaşırdı. Ayrıca terziler, insanların günlük kullandığı özel eşyalarına da sıklıkla temas ediyordu.

Hastalık emarelerinin sıkça görüldüğü yerler sırasıyla şu şekildeydi: Dergâh-ı Nestûrî (22 cizyegüzâr), Dergâh-1 Ya'kûb (14), Kal'a-1 Ya'kûb (13), Tellkeyf (9), Karakuş (9), Musul'daki perakendeler (9), Yahudi cemaati (8), Başbeyte perakendesi (3), Bartalla (3) ve Tellkeyf Perakendesi (1). İlk iki mahallenin nüfusu yoğun olmakla birlikte paranın sıklıkla dolaşımda olduğu muhitlerdendi. Hastalığın bulaşma riski muhtemelen bu yüzden buralarda yüksekti. Sayısal verilere göre hastalık en fazla Musul'un merkezinde hissedilmişti. Bunların dışında dakkâk, bennâ, taşçı, astarcı, bezzaz, nekkâr, kilise hizmetçisi, hizmetkâr, kılıççı, demirci, debbağ, kibritçi, savleci, çerçi, tarakçı, kürkçü, eskici ve attarlarda da çiçeğin tesiri görülmüştür. Çiçeğe yakalandığı kesin olarak saptanamayan, ancak bedenlerinde izler ve yaralar taşıyan cizyegüzârlar da vardı; yüzü, üst dudağı, alnı, kaşı veya gözü nişanlı veya lekeli olanlar, eli veya gözü hicranlılar, boynu veya yüzü eğri olanlar, kör veya bir gözünü kaybedenler, üst dudağı yarık veya alt dudağı gedik olan ve yanağı yaralılar gibi. Alkuş, Ba'şîka, İmadiye, Mardin, Diyarbakır, Bağdat ve İran'dan gelen yabancılarda da hastalığın izlerine rastlanmıştır.

\section{Sonuç}

Bu çalışma, Musul şehrindeki gayrimüslim zanaatkârların listesini sunması açısından önemlidir.

1691 cizye fermanından sonra "yoğunlaşan" mufassal cizye defterleri, Osmanlıdaki zimmilerin tarih yazımında önemli bir merhaledir; çünkü bu defterler zimmilerin yerleşimlerine, mesleklerine ve bölgesel ilişkilerine ışı tutmuştur.

Müeyyidelerini toplumların iktisadi, toplumsal, kültürel ve düşünce yapılarına göre uygulayan Osmanlı, bu yolla, tebaanın edebî mirasının şekillenmesinde ortak rol oynamıştır.

225 BOA, KK.d nr.3813, s. 1-11, 17, 35-37. 
Cizye defterlerindeki verilere göre Musul şehrinde fakir gayrimüslimlerin oranı \% 64 iken, Hama ve Humus merkezinde bu oran \% 50'ye yakındı. Musul kırsalından kente yapılan göçler \% 29 nispetindeydi. Humus'a kıyasla dinî kimliği yansıtan mahallelere yerleşme eğiliminin Musul ve Hama'da daha yüksek olması, Müslim-gayrimüslim ayrışmasının belirginliğine işaretti. Bu eğilim, muhtemelen Musul'a gelen Mardinli, İmadiyeli ve Diyarbakırlı Yahudi çerçileri Yahudi mahallesine yöneltmişti. Doğrusu çerçilerin, dokumacı ve kuyumcu gibi ticari getirisi yüksek olmayan attar, boncukçu, çerçi, eskici, hakkâk, kâlcı ve kirişçilerin yoğunlaştığı Yahudi Mahallesi'nden başka bir mahalleyi yeğlemeleri için farklı bir sebep gözükmüyordu.

Musul Kazası'nda dört çeşit nüfus hareketi saptanmıştır: Çeşitli şehirlerden ve kendi kırsal bölgesinden şehre doğru hareketler, şehir içi hareketler ve Musul'un köyleri arasındaki hareketlerdir ki kırsalda en fazla perakende, Karakuş'taydı. Dördüncü tür hareketler, kırsalın ağırlaşan şartları yanında bazı köylerin anayol üzerinde bulunması ve pazar yeri olmasından kaynaklanıyordu. Musul'da en fazla Mardinli, Diyarbakırlı ve Bağdatlılara rastlanması, bu şehirler için Musul'un önemine işaretti. Farklı şehirlerden gelenlerin \% 40’’ bugünkü Doğu ve Güneydoğu Anadolu bölgesinden olduğuna bakılırsa, Musul, Anadolu’nun gayrimüslimleri için önemliydi. Musul'daki perakendeler çoğunlukla Tokat-Kilis-Halep çizgisinin doğusundaki şehirlerdendi.

Nüfus hareketlerinin failleri, gelip-geçenler veya kazanç sağlama amacında olan perakendelerdi. Şam’a kıyasla perakendelerin sık uğradığı Musul'da Şam, Hama, Humus ve Doğu Akdeniz şehirlerinden cizyegüzârlara rastlanmaması Musul'un, Halep'in gölgesinde kaldığını mı gösteriyor? Trablusşam'da Halepliler çoğunluktayken, neden Musullu cizyegüzârlar yoktu? Halep cizye defterinde bölgesel kimliklerin kaydedilmediğinden, Halep’e yapılan göçlere ilişkin bilgilere ulaşılmamıştır.

İdarecilerin aç gözlülüğü, eşkıya, kıtlık, taun, pahalılık, kuraklık ve çekirge istilası reayanın dağılmasına neden olmuştu. Bazı köylerin bayındırlaştırılma girişimlerine rağmen, Musul'da cizyegüzârları tamamen dağılan köyler vardı. Musul, Hama ve Humus Kazası'nın kırsalındaki gayrimüslimlerin \% 70'ten daha fazlası fakirdi. Yol üzerinde bulunmasının getirdiği dezavantajlar, eşkıya hareketleri, cizyedarların baskısı ve ağır hayat şartlarından birçok reayası dağılmasına rağmen Tellkeyf ve ayrıca Karakuş cizyegüzârların en fazla bulunduğu köylerdendi. Musul kırsalında fakir oranın \% 77 olması, Bâşbeyte’nin tamamen dağılması 
gayrimüslimler açısından iş ve kazanç kapısı olarak şehirlerin önemine işaretti. Kırsaldaki gerileyiş sadece Musul'da görülen bir vakı değildi; Hama, Humus ve Şam için de geçerliydi. Humus'taki vaziyetse daha vahimdi; çünkü Humus'un merkezindeki cizyegüzârların oranı takriben \% 95 iken, kırsalda bu oran yaklaşık \% 5 'ti. Bütün bunlardan, gayrimüslimlerin kırsaldan iaşesini sağlayamadığ anlaşılıyor.

Osmanlı'nın Acemle mücadelesi, Musul'un serhat şehri olması ve nehirlere konumu, zanaatkârların ihtiyacı, doğu-batı ticaret yolu güzergâhında bulunmasının getirdiği üstünlüklerle birlikte bunlardan istifade arzusu ve diğer şehirlerin iktisadi ve toplumsal vaziyeti, şehirde icra edilen zanaatların türünü, mekânsal yerleşimlerini ve niceliğini belirleyici etmenler olmuştur. Nitekim Musul'da farklı bölgelerden rencber, çulha, terzi, kılıççı, kürkçü ve kuyumcular vardı. Gayrimüslimler arasında en fazla çırağa sahip dokumacılık, dokuma sektöründeki çıraklar için bir iaşe kapısıydı. Şehirdeki göçmen çırakların oranı \% 27 olup çoğunluğu terzi, çulha ve kuyumcuydu. Hama ve Humus'ta da bennâlara ilaveten çulha ve kuyumcuların en fazla çırağa sahip olması, bunların daha yoğun iş hacmi ve işbölümüne gereksinim duymasındandı. Kılıççı esnafının Musul'da \% 4, Hama’da $\% 1$, Humus'ta \% 0,5 ve Şam'daysa kayıtlı olmaması Musul'un askerî ve stratejik konumunun sonucuydu.

Musul gayrimüslimlerinin takriben \% 97'sinin mesleğinin bilinmesi, iktisadi hayatlarına dair tespitleri ve varsayımları güvenilir kılmıştır. Bu oranın \% 42'si dokumacilık ve dokumacılığın yan dallarında çalışan zanaatkârlardı. Hama (\% 27) ve Humus'taysa (\% 36) bu oran biraz daha düşüktü ve buralarda gayrimüslim boyacı esnafına rastlanmamışır. Musul'da dokumacılık ve yan kollardaki zanaatların \% 30’u Dergâh-1 Nestûrîde, \% 30'u ise Dergâh-1 Ya'kûb'da faaldi. Şehrin merkezî bir mevkiinde veya buraya yakın bir yerde bulunan Dergâh-1 Nestûrî astarcı, bezzaz, boyacı, çulha, tokmakçı, tarakçı, mimar, kuyumcu ve kuyumcu çıraklarının çoğunu bünyesinde toplamıştı. Bu vasfı emek, sermeye ve zanaat sahibi rencberlerin çoğunluğunun da ilgisini çekiyordu. Nitekim Musul, Hama ve Humus gayrimüslimleri arasında rencberler sayısal olarak ilk sıradaydı.

En fazla boyacı çırağı, çulha çırağı ve terzi çırağının sakin olduğu Dergâh-1 Ya‘kûb ise Dergâh-1 Nestûrîden sonra bennâ, astarcı, boyacı ve kuyumcu çırağının çoğunlukta olduğu mahallelerden ikincisiydi. Ticaretin omurgasını oluşturan bu zanaatkârların, kervanların, tüccarın veya sermaye ve zanaat sahiplerinin nakliye ihtiyaçlarını karşılayan semerci esnafının \% 58'inin bu iki mahallede 
ikameti tevafuktur. Dergâh-1 Nestûrî̀de, Hama ve Humus'taysa Nasâra mahallelerinde bennâ, çulha ve kuyumcuların ortak semtlerde yoğunlaşmaları, tüketici ve sermaye sahiplerinin ticari açıdan faal merkezlere yönelme düşüncelerine dair esnafın zihninde oluşan farkındalık ile yatırım ve alış-verişlerden sağlanacak fırsatlardan nemalanabilecekleri ve getiri potansiyeli yüksek semtleri tercihlerinden kaynaklanıyordu.

Van, Bitlis ve Diyarbakırlı kürk tacirleri, mazı ve kürk ticaretinin güzergâhındaki Musul'un olanaklarından yararlanıyordu. Diyarbakırlı kılıççı, ketenci ve pabuççuları için de Musul bir kazanç kapısıydı. Musul'da debbağlarla pabuççuların aynı mahallede kaydedilmeleri imalatta bir işbölümünün göstergesiydi. İş bölümü sadece deri sektörüyle sınırlı değildi. Nehir taşımacılığı kelek üretiminde keçi/koyun yetiştiricisi veya tüccarı, terzi, keresteci, dülger, keçeci ve amelelerin ortak rol almasını sağlamıştır. Bunlardan bazılarının Kal'a-1 Ya kûb’da çoğunlukta olması büyük olasılıkla mahalleyi nehir nakliyecilerinin uğrağı haline getirmişti. Ayrıca demirci, demirci çırağı, iğci, kalaycı, kazanc1, neccar, çöpçü, kürkçü, debbağ ve debbağ çırağı gibi ticari kazancı kuyumcu ve dokumacılar kadar yüksek olmamakla birlikte görüntü ve gürültü kirliliğine sebep olan bu mesleklerin sayısal üstünlüğü Kal'a-1 Ya'kûb’daydı.

Hama ve Humus gayrimüslimleri arasında ekmekçilere ve nalbantlara rastlanırken, Musul'dakiler arasında bu mesleklere ilaveten kasap ve değirmencilere de rastlanmaması "Osmanlı'nın hudut politikası”nın bir gereği miydi? Yani bu meslekler ya devlet emriyle Müslümanların tekelindeydi ya da vergiden muaflardı. Bu tür verilerin ispatlanması için hudut eyaletlerini kapsayan "Osmanlı'nın Hudut Politikaları" başlığı altında bir çalışmaya ihtiyaç vardır.

Buna ilaveten Musul'da Müslüman esnafa ilişkin yapılacak benzeri bir çalışma, gayrimüslim esnafla ilgili tespitleri hem olgunlaştıracak hem de artıracaktır. Çünkü gayrimüslim esnaf arasındaki çırak oranının sadece \% 13 olması ya gayrimüslim zanaatkârlarla çalışan, ancak Müslüman oldukları için deftere kaydedilmeyen çırakların varlığından ya da muafiyet gibi devletin vergi politikasından kaynaklanıyordu. Gayrimüslim çırakların oranı Hama’da \% 9 ve Humus'taysa \% 6 gibi düşük seviyelerdeydi.

$\mathrm{Bu}$ çalışmada verilen yüzde oranları cizye defterlerindeki kayıtlar dikkate alınarak ortaya konmuştur. 
Öz — Osmanlı kenti-gayrimüslim ilişkisi çerçevesinde cizye defterlerinin, Osmanlı gayrimüslimleri (zimmiler) tarihine ve Osmanlı şehir tarihine katkısını belirlemek araştırmanın problemi olarak ele alınmıştır.

Araştırmanın genel amacı Musul Kazası'ndaki gayrimüslimlerin kentsel-kırsal yerleşimlerini, göç ve göçmenlerin niteliğini, zanaatların mekânsal örgütlenmesini, Musul'un bölgesel ilişkilerini ve çiçek hastalığının etkilerini ortaya koymaktır.

Diğer amaçlarsa şunlardır: Kentsel-kırsal nüfus ve gelir düzeyi nedir? Toplumsal ve demografik karakteristiği belirlemede defter terminolojisindeki kavram karmaşasının etkisi nedir? Zanaatların niteliği ve niceliği ile mahallelerin karakteristiği arasındaki ilişki nedir? Usta-çırak sayısındaki orantısızlığın nedeni nedir? Serhat şehirlerine ait cizye defterlerinin içerikleri ile Osmanlı hudut politikaları arasındaki ilişki nedir? Çiçek hastalığının yayılması ile dokumacılık arasındaki ilişki nedir?

Araştırmanın esasını 1103/1691-92 tarihli Musul Kazası cizye defteri oluşturmuştur. Defterdeki verilerin yorumlanmasında Osmanlı Arşivi'ndeki (İstanbul'da) çeşitli belge ve defterler ile Diyarbakır ve Mardin şer iyye sicilleri kullanılmıştır.

Araştırmada şu bulgulara ulaşılmıştır: Kazadaki yerli gayrimüslimlerin \% 49’u kentte sakin olup \% 64'ü ednâ (gelir düzeyi açısından fakir) idi. Kırsaldaki ednâların oranıysa \% 77 idi. Kentte kırsal alandan (oranı \% 29'dur) ve farklı kentlerden (oranı \% 61'dir) göçmenlere rastlanmıştır. "Kentte iş tutanlar" ve "gelip-gidenler" olarak sınıflandırılan perakendelerin çoğunluğunu oluşturan rencberler; hamalları, zanaat ve sermaye sahiplerini kapsamıştır. Rencber, mimar, kuyumcu, semerci, dokumacı ve dokumacılığın yan kollarını oluşturan zanaatkârların çoğunluğu Dergâh-ı Nestûrî Mahallesi'ndeydi. Nehir nakliye araçlarının üretiminde rol oynayan esnaf aynı mahallede yoğunlaşmıştı. Bazı Müslüman çıraklar, gayrimüslim ustalarla çalışıyordu. Şehirdeki çırakların oranı \% 13'tü. Göçmen çırakların oranıysa \% 26 idi. Kuyumcuların 1/3'i, kılıççılarınsa \% 31'i göçmendi. Musul'da gayrimüslim ekmekçi, kasap, değirmenci ve nalbantlara rastlanmamıştır. Çiçek salgını en fazla terzi, rencber, çulha, boyacı ve marangoz esnafını etkilemiştir. Atasözlerinde Osmanlı vergi yaptırımlarının izlerine rastlanmıştır.

Gayrimüslimler açısından kırsal ve kentsel nüfus arasında ciddi bir fark olmamasına rağmen kırsal yoksulluk kentsel yoksulluktan yüksekti. Kırsaldaki düşük gelir düzeyi ile Musul'un idari ve coğrafi konumunun sağladığı istihdam alanları ve ticaret; emek, zanaat ve (düşük/yüksek) sermaye sahiplerini kente ve özellikle kentin işlek mahallelerine yöneltmiştir.

Anahtar kelimeler: Cizye Defterleri, Osmanlı'da Gayrimüslimler, Musul'un Yahudileri ve Hristiyanları, Ortadoğu'da Zanaat ve Zanaatkârlar, Ortadoğu'da Göç ve Göçmenler, Osmanlı'da Çiç̧ek Hastalığı, Türk ve Arap Atasözleri 


\section{Kaynakça}

\section{Arşiv Belgeleri}

BOA, 'Alî Emîri Süleyman II (AE.SSÜL.II), 20/2081

BOA, 'Alî Emîri Ahmed II (AE.SAMD.II), 18/1977, 90/8944

BOA, Bâb-1 Defteri Başmuhâsebe Kalemi (D. BŞM.d), 184

BOA, Cevdet Maliye (C.ML), 342/14069, 448/26539

BOA, Bâb-1 Defteri Cizye Muhâsebesi Kalemi (D.CMH), 26681, 217/1, 219/52, $236 / 120$

BOA, İbnü'l-Emîn Dâhiliye (İE.DH), 9/913, 10/980

BOA, Kamil Kepeci (KK.d), 3508, 3509, 3813, 3820

BOA, Maliyeden Müdevver Defterler (MAD), 1215, 2467, 2742, 2931, 2935, 3639, 3649, 9834, 9848

BOA, Mühimme Defterleri (A.DVNS.MHM.d), 23, 36, 40, 46, 60, 87, 102, 104

BOA, Tahrir Defterleri (TD.d), 195, 308, 660, 1109

Millî Kütüphane, Diyarbakır Şer'iyye Sicilleri (DŞS), 316

Millî Kütüphane, Mardin Şer iyye Sicilleri (MŞS), 203, 248, 259

\section{Yayınlanmış Eserler}

12 Numaralı Mühimme Defteri (978-979/1570-1571): Özet, Transkripsiyon ve Indeks, I, Ankara: Başbakanlık Devlet Arşivleri Genel Müdürlüğü Osmanlı Arşivi Daire Başkanlığı Yayınları 1996.

'Abbâs el-'Azzâvî el-Mahâmî: Mevsû'atü Târîhi'l-'Irâk Beyne İhtilâleyni el-'Ahdi'l-'Osmânî es-Sânîh. 1048 -m. 1638/h. 1163-m. 1750, el-Mücelledü’l-Hâmis, Basım Yeri Yok: ed-Dârü'l-'Arabiyyetü li'l-Mevsû́âti Tarihsiz.

Ahmet Vefik Paşa, Atalar Sözü Müntehabât-ı Durûb-ı Emsâl, haz. Recep Duymaz, İstanbul: Gökkubbe 2005.

Akdağ, Mustafa: Türkiyénin İktisadî ve İctimâ̂ Tarihi 1 (1243-1453), I, İstanbul: Cem Yayınevi 1995.

Aksoy, Ömer Asım: Atasözleri ve Deyimleri Sözlüğ̈̈ I Atasözleri Sözlü̆̆̈̈, Ankara: Ankara Üniversitesi Basımevi 1971.

Alanoğlu, Murat: "86 Numaralı Mühimme Defterinin Özeti Transkripsiyonu ve Değerlendirilmesi”, Yüksek Lisans Tezi, Erzurum, 2010.

Andreasyan, Hrand Der: Polonyalı Simeon'un Seyahatnâmesi (1608-1619), İstanbul: Everest Yayınları 2013. 
Anonim Osmanlı Tarihi (1099-1116/1688-1704), Abdülkadir Özcan haz., Ankara: Türk Tarih Kurumu Yayınları 2000.

Ayverdi, İlhan: Asırlar Boyu Târihî Seyri İçinde Misalli Büyük Türkçe Sözlük, I-II-III, İstanbul: Kubbealtı Lugatı 2011.

Bâbû İshak, Rafầîl: Târîhü Nasârâül-'Irâk münzü intişârün-Nasrâniyye fi'l-âktâri'l'Irâkiyye ilâ eyyâminâ, Bağdad: Matba'atü'l-Mansûr 1948.

Bayatlı, Nilüfer: XVI. Yüzyılda Musul Eyâleti, Ankara: Türk Tarih Kurumu Basımevi 1999.

Darkot, Besim: "Musul”, İslâm Ansiklopedisi, VIII (1979), s. 741-744.

Dilçin, Dehri: Edebiyatımızda Atasözleri (1. Kitap), İstanbul: Türk Dil Kurumu Yayınları 1945.

Ed-Dîveci, Sa îd: “Kal'atü’l-Mevsıl fî muhtelifi'l-'usûri”, Mecelletü Sûmer, el-Mücelledü’l'Âşsir, el-cüz'ü'l-evvelü (Bağdad 1954), s. 1-24.

.: “Cisrül-Mevsıl fî muhtelifi'l-'usûri”, Mecelletü Sûmer, XII (Bağdad 1956), s. 1-123. .: "el-Mevsil”, el-Mu'temerü̈t-tıbbîr-rebîîl-evvelü li'l-cem 'iyyeti't-tıbbiyyeti'l-'Irâkıyyeti bi'l-iştirâki ma' fer üll-cem iyyeti bi'l-Mevsıl, (el-Mevsıl 1964), s. 1-16.

.......: Târîhü̈l-Mevsıl, II, Basım yeri yok: Basımevi yok 2001.

........ "Sınâ'tü’n-Nesîci fîll-Mevsıl”, bi-münâsebeti ihtifâlâti'l-münşe’atül-'âmmeti li'l-gazeli ve’n-nesîci fîl-Mevsıl bi-mürûri "30" 'âmmen 'alâ bedelihâ bi'l-intâci 26/03/195726/03/1987, (Basıldığı Yer Yok 1987), s. 4-29.

.......: Ticâretül-Mevsıl fî muhtelifi'l-usûri, el-Mevsıl: Müdîriyyetü Dâri İbni'l-Esîr li'ttıbâ'a ve’n-neşri 2013.

El-Eb Yûsuf Kûşâkc1: el-Emsâlüssşşa 'biyyetü’l-Halebiyye ve emsâlü Mârdîn, el-cüz'ü’s-sânî, Haleb: Matba'atü'l-İhsân 1978.

Erpolat, Mehmet Salih: “Cizye Defterlerinin Sosyal ve İktisadî Tarih Araştırmaları Açısından Önemi: Diyarbakır Örneği”, Akademik Araştırma ve Dayanısma Derneği Sosyal Bilimler Araştırma Dergisi (SBArD), 4 (2015), s. 189-204.

Evliya Çelebi: Seyâhatnâme (III. ve IV), Seyit Ali Kahraman haz., I, Ankara: Atatürk Kültür, Dil ve Tarih Yüksek Kurumu Türk Tarih Kurumu Yayınları 2013.

Genç, Mehmet: "Mukâtaa”, TDV İslâm Ansiklopedisi, XXXI (2006) s.129-132.

Göyünç, Nejat: "Dicle ve Firat Nehirlerinde Nakliyat”, Belleten, LXV/243, (2001), s. 655-665.

Gündüz, Ahmet: Osmanlı İdaresinde Musul (1523-1639), Elazığ: Fırat Üniversitesi Bas1mevi 2003.

Giuseppe Di Santa Maria Sebastiani: Rıhletü Sebastiyânî el-Eb Cûzîbe Dî Sântâ Mâriyâ el-Kermelî İlâ el-'Irâk Senetü 1666 m., Betrus Haddâd trc., Beyrût: ed-Dârü'l'Arabiyyetü li'l-Mevsû́âti 2006. 
Güvâhî: Pend-nâme (Öğütler ve Atasözleri), haz. Mehmet Hangirmen, Ankara: Kültür ve Turizm Bakanlığ Yayınları 1983.

Honigmann, E. ve Bosworth, C. E.: "Al-Mawsil", Encyclopaedia of Islam 2 ${ }^{\text {nd }}$, VI, 1991, s. 899-902.

Hut, Davut: Musul Vilayeti’nin İdarî, İktisadî ve Sosyal Yapısı (1864-1909), Doktora Tezi Marmara Üniversitesi, 2006.

İnalcık, Halil: “Cizye”, TDV İslâm Ansiklopedisi, VIII (1993), s. 45-48.

Marufoğlu, Sinan: Osmanl Döneminde Kuzey Irak (1831-1914), İstanbul: Eren Yayınc1lik 1998.

Stefanos Yerasimos ed.: Tavernier Seyahatnamesi, Teoman Tunçdoğan çev., İstanbul: Kitap Yayınevi 2010.

......:Tournefort Seyahatnamesi, çev. Ali Berktay, I, İstanbul: Kitap Yayınevi 2013.

Khoury, Dina Rizk: Osmanl Imparatorluğu’nda Devlet ve Taşra Toplumu Musul, 15401834, Ülkün Tansel çev., İstanbul: Tarih Vakfi Yurt Yayınları 2003.

Kurt, İhsan: Türk Atasözlerine Psikolojik Bir Yaklaşım, Ankara: Kültür Bakanlığı Yayınları 1991.

Masters, Bruce: Christians and Jews in the Ottoman Arab World: The Roots of Sectarianism, Cambridge: Cambridge University Press 2001.

Mehmed Ali el-Ünsî: Kâmûsüll-lügati'l-Osmâniyyeti'l-müsemmâ dirârül-lâmi'âti fî müntehabâti'l-lügâti, Beyrût: Matba'a-1 Cerîde-i Beyrût 1318.

Muhammed Ra'ûf el-Gulâmî: Kitâbü'l-müreddedi'l-emsâli'l-âmmiyyeti'l-Mevsıliyyeti, nşr. Mü’eyyed el-Gulâmî, Bağdâd: Matba'atü’ş-Şefîk 1384/1964.

Muhammed Saîd El-Kâsimî v.dğr.: Kâmûsü’s-Sınâ'âti’ş-Şamiyyeti, II, nşr. Zâfir el-Kâsimî, Dımaşk: ed-Dârü Talâs li Dırâsâti ve't-Tercümeti ve’n-Neşri 1988.

Nedkoff, Boris Christoff: "Osmanlı İmparatorluğunda Cizye (Baş Vergisi)”, çev. Şinasi Altundağ, Belleten, VIII, 32 (1944), s. 599-652.

Alizâde, Samed: Oğuznâme (Emsâl-i Mehmedali) XVI. yy.da Yazılmış Türk Atasözleri Kitabı, Eklerle yay. Ali Haydar Bayat, İstanbul: Türk Dünyası Araştırmaları Vakfı 1992.

Orhonlu, Cengiz-Işıssal, Turgut: "Osmanlı Devrinde Nehir Nakliyatı Hakkında Araştırmalar Dicle ve Fırat Nehirlerinde Nakliyat”, Tarih Dergisi, XII/17-18 (1963), s. 77-102.

Râşid Mehmed Efendi Çelebizâde İ́smail Âsım Efendi: Târîh-i Râşid ve Zeyli, haz. Abdülkadir Özcan-Yunus Uğur-Baki Çakır-Ahmet Zeki İzgöer, İstanbul: Klasik Yayınları 2013, I.

Raymond, Andre: Osmanlı Döneminde Arap Kentleri, çev. Ali Berktay, İstanbul: Alfa/Tarih 2018. 
Samıkıran, Oğuzhan: "Nefs-i Şam Örneğinde Gayrimüslimlerin Nüfus ve Mesleklerine Dair Bir Araştırma”, Avrasya İncelemeleri Dergisi (AVID), III/2 (2014), s.183-250.

Süleyman Sầiğ el-Mevsılî: Târîhül-Mevsıl, el-cüz'ü’l-evvelü, Misır: el-Matba'atü's-Selefiyye, Tarihsiz.

Süleyman Sûdî: Osmanlı Vergi Düzeni (Defter-i Muktesid), M. Ali Ünal haz., Isparta: Fakülte Kitabevi 2008.

Şemseddin Sami, Kâmûsül-Â'lâm, V-VI, İstanbul: Mehrân Matba'ası, 1316.

: Kâmûs-u Türkî, İstanbul: Çağrı Yayınları 2016.

Eş-Şeyhü’l-İmâm Şihâbeddin Ebî Abdullah Yâkût bin Abdullah el-Hamevî er-Rûmî elBağdâdî, Mu'cemüll-Büldân, I-II-IV-V, Beyrût: Dârü Sâdır 1397/1977.

Şinasi İbrahim: Durûb-u Emsâl-i 'Osmâniyye, Kostantıniyye: Matba'a-ı Ebu’z-Zıyâ 1302.

Tabakoğlu, Ahmet: Türk İktisat Tarihi, İstanbul: Dergâh Yayınları 1997.

Tulum, Mertol: 17. Yüzyıl Türkçesi ve Söz Varlı̆ğ, Ankara: Atatürk Kültür, Dil ve Tarih Yüksek Kurumu Türk Dil Kurumu Yayınları 2011.

Türkhan, M. Sait: 18. Yüzyılda Doğu Akdeniz'de Ticaret ve Haleb, Doktora Tezi, İstanbul Üniversitesi, 2014.

El-'Udûl, Câsim Muhammed Hasan: “el-Kevârisü ve'l-zavâhirü't-tabî'iyyetü fi'l-Mevsıl min hilâli mü'ellifâti'l-mü’ errihi'l-Mevsılî Yâsîn bin Hayrullah el-Hatîb el-Ömerî”, Dırâsâtü Mevsıliyyetü, 13 Basım Yeri Yok, Temmuz 2006.

Uzunçarşılı, İsmail Hakkı: Osmanlı Tarihi, Ankara: Türk Tarih Kurumu Basımevi 1995, III/I.

Vak'anüvis Subhî Mehmed Efendi, Subhî Tarihi, Sâmî ve Şâkir Tarihleri ile Birlikte 17301744 (İnceleme ve Karşılaştırmalı Metin), Mesut Aydıner haz., İstanbul: Kitabevi Yayınları 2007.

Yâsîn bin Hayrullah el-Hatîbü'l-Ömerî, Meniyyetül-udebâi fî târîhi'l-Mevsıli'l-hadbâ',. Sa'îd ed-Dîveci nşr., el-Mevsıl: Matba'atü'l-Hedef 1374/1955.

Yılmaz, Coşkun ed.: Evliya Çelebi Atlası, İstanbul: Medam Yayınları 2012. 
MUSUL KAZASI'NIN CİZYEGÜZÂRLARI VE BÖLGESEL İLİŞILLERİ

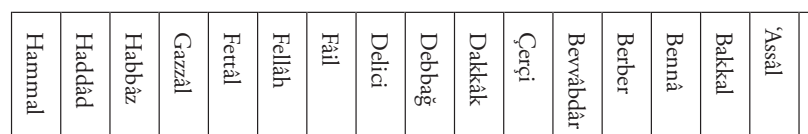

뭉

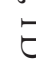

¿

ळे

s

A

ज्

命

ث

品

ง

(2)

$\frac{\frac{2}{2}}{\frac{2}{\frac{2}{2}}}$

资
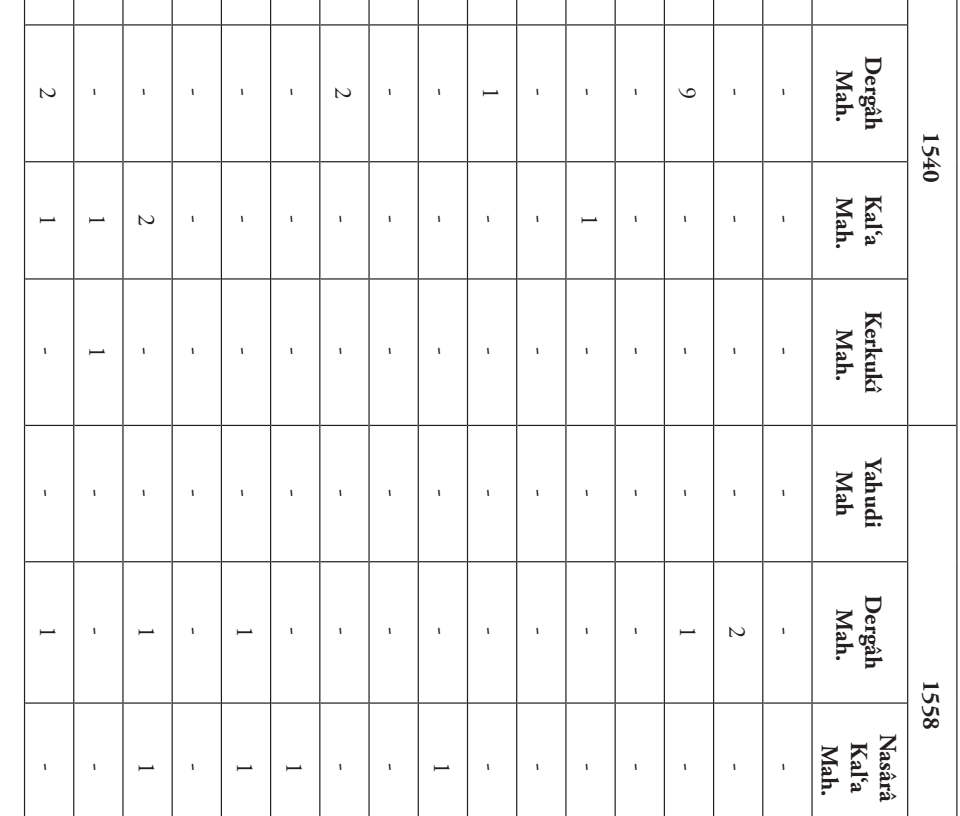

$\overrightarrow{S_{\infty}}$

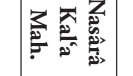

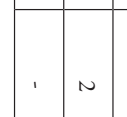

旅总

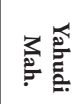
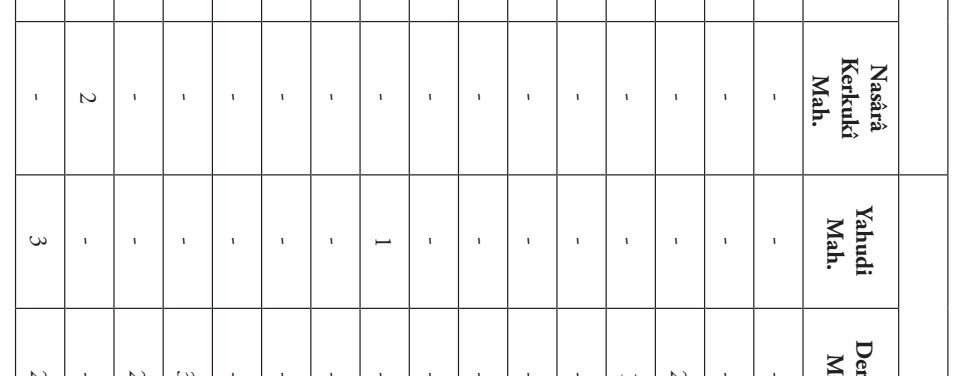

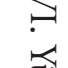
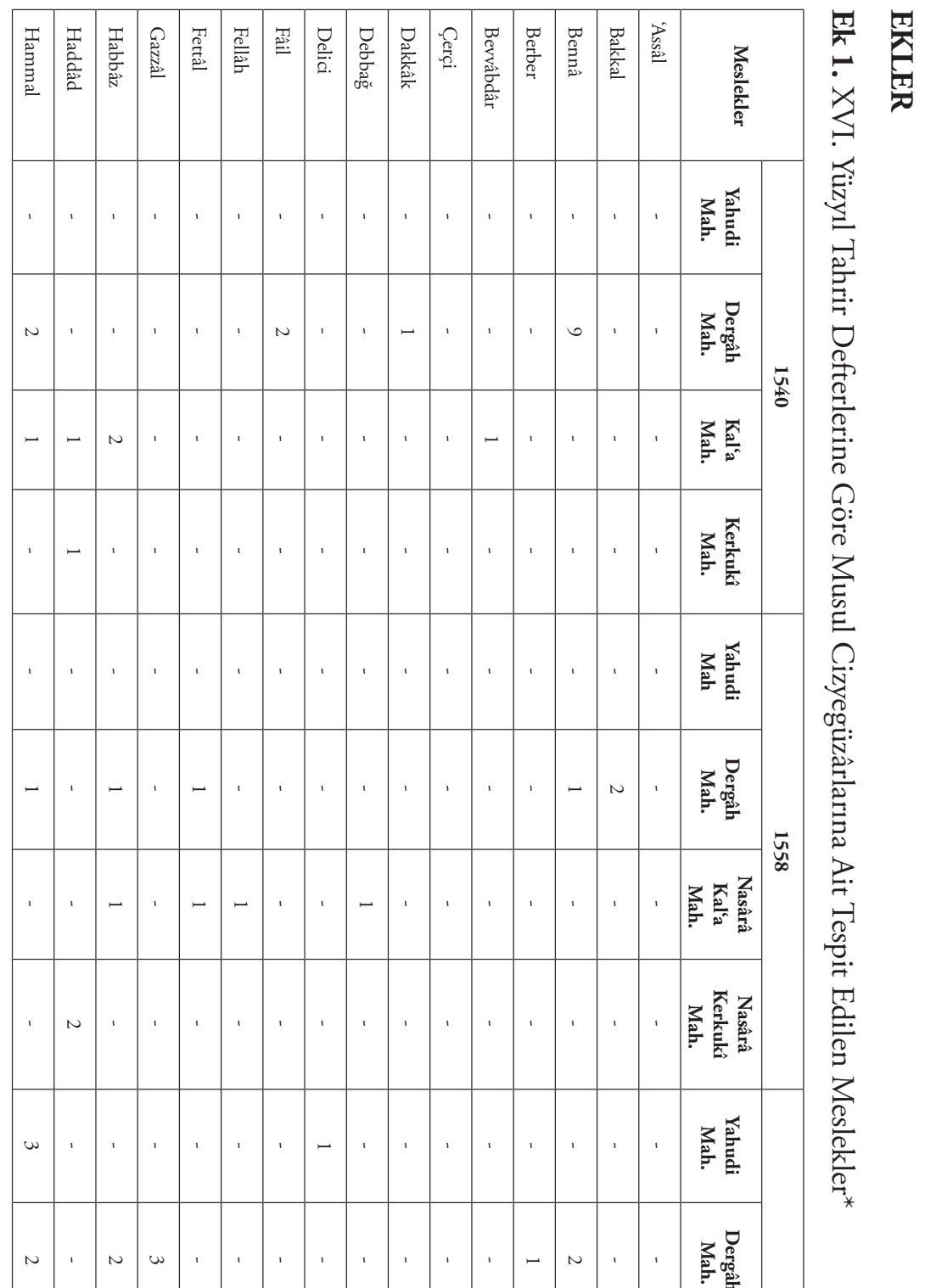

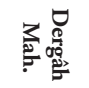


OĞUZHAN SAMIKIRAN

\begin{tabular}{|c|c|c|c|c|c|c|c|c|c|c|c|c|c|c|c|c|c|c|c|c|c|c|c|}
\hline 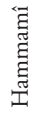 & 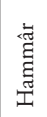 & 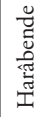 & $\begin{array}{l}E \\
\text { 壱 } \\
\text { Th }\end{array}$ & 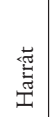 & 疍 & 式 & 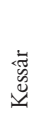 & 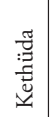 & 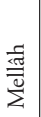 & 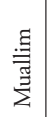 & 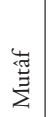 & 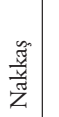 & $\begin{array}{l}\text { 节 } \\
\text { ž }\end{array}$ & 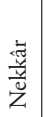 & 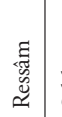 & 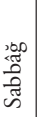 & 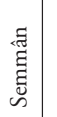 & 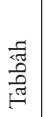 & 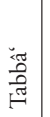 & 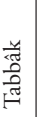 & $\begin{array}{l}\text { 氶 } \\
\text { 空 }\end{array}$ & 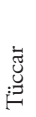 & $\begin{array}{l}\text { 재 } \\
\text { 递 }\end{array}$ \\
\hline
\end{tabular}


